\title{
Observed and Projected Hydroclimate Changes in the Andes
}

\begin{abstract}
José Daniel Pabón-Caicedo ${ }^{*}$, Paola A. Arias², Andrea F. Carril3,4, Jhan Carlo Espinoza ${ }^{5}$, Lluís Fita Borrel ${ }^{3,4}$, Katerina Goubanova ${ }^{6}$, Waldo Lavado-Casimiro ${ }^{7}$, Mariano Masiokas ${ }^{8}$, Silvina Solman ${ }^{9,3,4}$ and Ricardo Villalba $a^{8,4}$
\end{abstract}

\begin{abstract}
'Departamento de Geografía, Universidad Nacional de Colombia, Bogotá DC, Colombia, ${ }^{2}$ Grupo de Ingeniería y Gestión Ambiental (GIGA), Escuela Ambiental, Facultad de Ingeniería, Universidad de Antioquia, Medellín, Colombia, ${ }^{3}$ Centro de Investigaciones del Mar y la Atmósfera (CIMA/UBA-CONICET), Ciudad Autónoma de Buenos Aires, Buenos Aires, Argentina, ${ }^{4}$ Institut Franco-Argentin d'Etudes sur le Climat et ses Impacts (UMI-IFAECI/CNRS-IRD-CONICET-UBA), Buenos Aires, Argentina, ${ }^{5}$ IRD, CNRS, G-INP, IGE (UMR 5001), Université Grenoble Alpes, Grenoble, France, ${ }^{6}$ Centro de Estudios Avanzados en Zonas Áridas (CEAZA), La Serena, Chile, ' Dirección de Hidrología, Servicio Nacional de Meteorología e Hidrología (SENAMHI), Lima, Peru, ${ }^{8}$ Instituto Argentino de Nivología, Glaciología y Ciencias Ambientales (IANIGLA), CCT-CONICET Mendoza, Mendoza, Argentina, ${ }^{9}$ Departamento de Ciencias de la Atmósfera y los Océanos DCAO-FCEN-UBA, Facultad de Ciencias Exactas y Naturales, Universidad de Buenos Aires, Buenos Aires, Argentina
\end{abstract}

\section{OPEN ACCESS}

Edited by: Bryan G. Mark,

The Ohio State University, United States

Reviewed by:

Eduardo Zorita,

Helmholtz Centre for Materials and Coastal Research (HZG),

Germany

Mario Bruno Rohrer, Meteodat $\mathrm{GmbH}$, Switzerland

*Correspondence:

José Daniel Pabón-Caicedo jdpabonc@unal.edu.co

Specialty section: This article was submitted to Atmospheric Science, a section of the journal Frontiers in Earth Science

Received: 21 October 2019 Accepted: 19 February 2020

Published: 17 March 2020

Citation:

Pabón-Caicedo JD, Arias PA, Carril AF, Espinoza JC, Borrel LF,

Goubanova K, Lavado-Casimiro W, Masiokas M, Solman S and Villalba $R$ (2020) Observed and Projected Hydroclimate Changes in the Andes.

Front. Earth Sci. 8:61.

doi: 10.3389/feart.2020.00061
The Andes is the most biodiverse region across the globe. In addition, some of the largest urban areas in South America are located within this region. Therefore, ecosystems and human population are affected by hydroclimate changes reported at global, regional and local scales. This paper summarizes progress of knowledge about long-term trends observed during the last two millennia over the entire Andes, with more detail for the period since the second half of the 20th century, and presents a synthesis of climate change projections by the end of the 21 st century. In particular, this paper focuses on temperature, precipitation and surface runoff in the Andes. Changes in the Andean cryosphere are not included here since this particular topic is discussed in other paper in this Frontiers special issue, and elsewhere (e.g. IPCC, 2019b). While previous works have reviewed the hydroclimate of South America and particular sectors (i.e., Amazon and La Plata basins, the Altiplano, Northern South America, etc.) this review includes for the first time the entire Andes region, considering all latitudinal ranges: tropical (North of $27^{\circ} \mathrm{S}$ ), subtropical $\left(27^{\circ} \mathrm{S}-37^{\circ} \mathrm{S}\right.$ ) and extratropical (South of $37^{\circ} \mathrm{S}$ ). This paper provides a comprehensive view of past and recent changes, as well as available climate change projections, over the entire Andean range. From this review, the main knowledge gaps are highlighted and urgent research necessities in order to provide more mechanistic understanding of hydroclimate changes in the Andes and more confident projections of its possible changes in association with global climate change.

Keywords: hydroclimate of the Andes, global change in the Andes, hydroclimate trends in the Andes, hydroclimate projections of the Andes, climate change in the Andes, climate change scenarios for the Andes

\section{INTRODUCTION}

Earth's environment has experienced long-term changes at planetary and continental scales, including changes of atmospheric circulation, ocean circulation, carbon cycle, nitrogen cycle, water cycle, sea-ice extension, sea level, food chains, biological diversity, air, and water composition, among many others (IPCC, 2013). Currently, these changes in consequence provoke several 
environmental impacts such as soil degradation, desertification, water and air pollution, water, energy and food scarcity, and health problems (IPCC, 2014, 2019a,b). In the Andean region, global environmental change has been evidenced mainly in the modification of land cover, land use and hydroclimate. Changes in land cover, which have impacted regional water and energy cycles, involves different time-scales driven by geological and climate processes, which shaped the altitudinal zones (types of vegetation and glaciers) throughout different periods of evolution (Flantua, 2017).

The interaction of regional atmospheric circulation with the Andean orography configures the current spatial and seasonal patterns of regional hydroclimate that are modified during long periods by other processes of the Earth's system, but this interaction varies along the Andes. In the north tropical Andes (North of $8^{\circ} \mathrm{S}$; Ecuador, Colombia, and Venezuela) and south tropical Andes $\left(8^{\circ} \mathrm{S}-27^{\circ} \mathrm{S}\right.$; Peru, Bolivia), the eastern side (inward) of the Cordillera allows the convergence of the atmospheric moisture provided by the Intertropical Convergence Zone (ITCZ) and by the South American Monsoon System (SAMS), generating a humid environment and a particular feature in the distribution of mass (atmospheric moisture) and energy (latent and sensible heat) (Makarieva and Gorshkov, 2007; Poveda et al., 2014; Espinoza et al., 2015; Chavez and Takahashi, 2017). On the eastern side of the subtropical Andes occur some of the strongest convective phenomena in the world (Altinger de Schwarzkopf and Rosso, 1982; Rasmussen et al., 2014; Zuluaga and Houze, 2015). Warm and wet air from the Amazonian region is transported along the eastern side of the Andes to the south generating a low-level jet. Strong and deep convection is generated when this air is uplifted by the "Sierras de Córdoba" and/or interacts with incoming south cold fronts and upper level disturbances. In the western side of the Southern Andes, the prevailing atmospheric moisture source is the evaporation from the Pacific Ocean (Gimeno et al., 2016). Moreover, the heavy orographic precipitation events during winter over the western slopes of the subtropical $\left(27^{\circ} \mathrm{S}-37^{\circ} \mathrm{S}\right)$ and extratropical Andes (South of $37^{\circ} \mathrm{S}$; mainly central and southern Chile) are strongly related to the intense water vapor transport from the southern Pacific, associated with extratropical cyclones (Viale and Nuñez, 2011), with the most intense rainfall occurring near and above the top of the mountain range (Falvey and Garreaud, 2007). These features of the Andean hydroclimate have experienced recent changes, as evidenced by several studies.

Previous research has provided new knowledge about Andean environment, allowing a better understanding of regional hydroclimate processes, including changes of hydroclimate patterns in different time scales. Most previous studies have been dedicated to specific regions into the Andes, while an integrated overview of the observed and projected hydroclimatic changes throughout the Andes is still lacking. In addition, there are still several research topics that need further development and surely new research problems have appeared that need to be solved. The review presented here focuses on the progress of knowledge about hydroclimate changes observed during the last two millennia as well as changes throughout the 20th Century, and climate change projections by the 21st Century over the Andes. First, we summarize current knowledge on the hydroclimate changes of the Andes during the last two millennia, followed by the changes during the last decades and a final section related to projected changes. We finalize with a description of the main concluding remarks.

\section{HYDROCLIMATE CHANGES IN THE ANDES DURING THE LAST TWO MILLENNIA}

Given the shortness of most instrumental climate records along the Andes, it is highly recommendable to rely on paleoenvironmental records to characterize natural climate variability and place current climate changes in the context of the last hundred to thousand years (Bradley, 2013). Particular emphasis has been given to the study of climatic variations during the last 2000 years, a period in which the conditions of the global climate system have been very similar to those of today (i.e., similar sea levels, approximately the same global ice cover, similar ocean circulation; Abram et al., 2016). In the effort to characterize past climates, the Andes provide a unique opportunity since along the region, the large diversity of paleo-indicators with its long geographic extension can be combined. The diverse topography of the Andes houses numerous high-resolution natural archives (seasonal to decadal information on climate), including ice cores, tree rings, speleothems, sedimentary records, boreholes and historical documents, among others. The Andes mountains constitute the richest region with high-resolution paleoenvironmental records in South America, and possibly in the entire Southern Hemisphere (SH; Villalba et al., 2009). Most of the highresolution paleoenvironmental records available in the Andes cover the last 200-500 years, but some of them exceed 2000 years (Lara and Villalba, 1993).

One of the major questions that persist in paleoclimate studies over the past millennia is to establish the global imprint of well-documented climate anomalies in the Northern Hemisphere $(\mathrm{NH})$. Periods abundantly documented in Europe and other mid-latitudes in the NH (Bradley, 2013), such as the Medieval Climate Anomaly (MCA, the warm period centered on the first centuries of the last millennium) or the Little Ice Age (LIA, the cold interval between the 15th and 19th centuries), have not yet been conclusively substantiated across South America. It is well known that glaciers advanced in the Andes concurrent with the LIA in Europe, but important differences in the timing of the ice advances along the Andes have already been documented (Masiokas et al., 2009). There is no consensus on the causes of the LIA, but most studies indicate that the LIA event was induced by the combination of frequent volcanic eruptions and weak solar radiation (Ahmed et al., 2013; Brönnimann et al., 2019). The existence of MCA has been proposed for South America for over 30 years (Villalba, 1994), but evidence of its occurrence is still scarce and not always straightforward. In this section, we review a selection of high-resolution (annual or seasonal) paleoclimatic studies 
based on records along the Andes to depict long-term variations in temperature and precipitation during the last 2000 years. Although the major emphasis is placed on precipitation changes, we also collect information on past temperature variations to illustrate the occurrence of long-term past climatic events showing major contrasts in hydroclimatic conditions such as droughts and floods.

\section{Temperature and Precipitation Changes in the Tropical Andes (North of $27^{\circ} \mathrm{S}$ )}

High-resolution proxies sensitive to temperature are scarce in the tropical Andes (Villalba et al., 2009). Based on ammonium $\left(\mathrm{NH}_{4}\right.$ + concentrations in ice cores from Nevado Illimani $\left(16^{\circ} 37^{\prime} \mathrm{S}\right.$, $67^{\circ} 46^{\prime} \mathrm{W}, 6300 \mathrm{~m}$ ), Bolivia, Kellerhals et al. (2010) reconstructed the temperature variations over the past 1600 years for this sector of tropical South America (Figure 1C). The Nevado Illimani temperature record shows relatively warm conditions during the first centuries of the last millennium followed by colder temperature between the 15th and 18th centuries. This record suggests that the MCA and LIA events were not limited to highlatitudes in the $\mathrm{NH}$ but also registered at $16^{\circ} \mathrm{S}$ in tropical South America. Nevertheless, while the LIA cooling in the $\mathrm{NH}$ has traditionally been associated with an increase in frequency and intensity of volcanic eruptions concurrent with a reduction in solar radiation (Bradley, 2013; Brönnimann et al., 2019), in the tropical Andes it was likely related to precipitation-temperature interactions. In the tropical Andes, increased cloud cover during wet conditions reduces air temperature, in line with the simultaneous occurrence of wet (dry) and cool (warm) periods in Pumacocha (Figure 1B) and Nevado Illimani (Figure 1C), respectively. Therefore, the simultaneous occurrence of longterm temperature anomalies at both mid-high $\mathrm{NH}$ latitudes and the tropical Andes may have been modulated by different drivers, but they might be dynamically connected. In the Nevado Illimani temperature reconstruction, the last decades of the 20th century are characterized by extremely warm temperatures that seem unprecedented in the context of the last 1600 years (Kellerhals et al., 2010).

Different paleo-indicators suggest that the changes in the SAMS during the last millennia were connected, to some extent, with the inter-hemispheric temperature gradient over the Atlantic Ocean, affecting hydroclimate of the Andes-Amazon region. The $\delta^{18} \mathrm{O}$ records from the laminated sediments in Laguna Pumacocha $\left(10^{\circ} 42^{\prime} \mathrm{S}, 76^{\circ} 04^{\prime} \mathrm{W}\right.$; Figure 1) show that the SAMS underwent in the last 2300 years decadal to multidecadal scale variability embedded in three main centennial-long intervals. The first period concurrent with the MCA in the $\mathrm{NH}$ was characterized by pronounced dryness. It was followed by markedly humid conditions during the LIA and a return to drier conditions since the beginning of the 20th century (Figure 1B). This current warm period (CWP) was characterized by the highest positive $\delta^{18} \mathrm{O}$ values throughout the 2300-year record (Bird et al., 2011). Thus, in response to pronounced cooling of the $\mathrm{NH}$ during the LIA (Figure 1A), the ITCZ would have moved toward the south, intensifying the monsoon activity in the Amazon basin and, in general, at the tropical portion of South America, including the tropical Andes (Bird et al., 2011; Vuille et al., 2012). On the contrary, during the warm periods of the MCA and CWP in the NH, the ITCZ migrated northward, reducing the transport of humidity toward the core of the SAMS domain, increasing the dry conditions over the tropical Andes. The long-term temporal oscillations in the $\delta^{18}$ Ocal record from Pumacocha were concurrent with variations recorded in the temperature reconstruction for $\mathrm{NH}$ (Figures 1A,B) by Moberg et al. (2005), suggesting that long-term changes in SAMS intensity are sensitive to fluctuations in ITCZ latitude on similar time scales (Bird et al., 2011; Novello et al., 2012, 2016; Vuille et al., 2012).

In the most arid southwestern sector of the South American Altiplano $\left(18-22^{\circ} \mathrm{S}, 67-69^{\circ} \mathrm{S}\right)$, the Polylepis tarapacana tree rings have been successfully used to reconstruct the variations in annual rainfall over the past seven centuries (Figure 1D; Morales et al., 2012). In this sector of the Altiplano, summer rains represent more than $80 \%$ of total annual precipitation. In the Altiplano, as in other regions of the Andes, El NiñoSouthern Oscillation (ENSO) events introduce an enormous interannual variability in precipitation, which somehow masks the long-term oscillations (Christie et al., 2009). However, the reconstruction of precipitation shows persistent long-term periods with abundant or reduced rainfalls (Figure 1D). The persistent rainfall reduction since the mid-19th century to the present is the most relevant long-term feature in the reconstruction. Since the 1930s, this persistent negative trend in precipitation has intensified, with the driest years since $1300 \mathrm{AD}$ occurring in the last 70 years.

\section{Precipitation Changes in the Subtropical Andes $\left(27^{\circ} \mathrm{S}-37^{\circ} \mathrm{S}\right)$}

Austrocedrus chilensis tree-ring records have recently been used to develop the first millennial reconstruction of rainfall in the subtropical Andes, particularly in central Chile (Garreaud et al., 2017). Similar to the Altiplano, rainfall in central Chile shows large ENSO-induced interannual variability (Montecinos and Aceituno, 2003). This enormous variability hinders to some extent the direct identification of long-term oscillations in rainfall during the last 1000 years, even though some longterm anomalies are well identified (Figure 1E). During the 11th and 13th centuries concurrent with the MCA, multi-decadal dry periods were observed. Preceded by a long wet period, the reduction of rainfall from the beginning of the 19th century to the CWP constitutes, as in the Altiplano, the most outstanding long-term feature of the last millennium. On the other hand, the two long-term periods with abundant rainfall do not seem to be associated with the colder (LIA) event, but with the transitions from the MCA to LIA, and from LIA to CWP, centered on the 14 th and early 18 th centuries (Figure 1E).

\section{Temperature and Precipitation Changes in the Extratropical Andes (South of $37^{\circ} \mathrm{S}$ )}

At extratropical latitudes, summer temperature reconstructions derived from Fitzroya cupressoides tree rings (Villalba, 1990; Lara and Villalba, 1993, and updates) indicate that the 20th century 


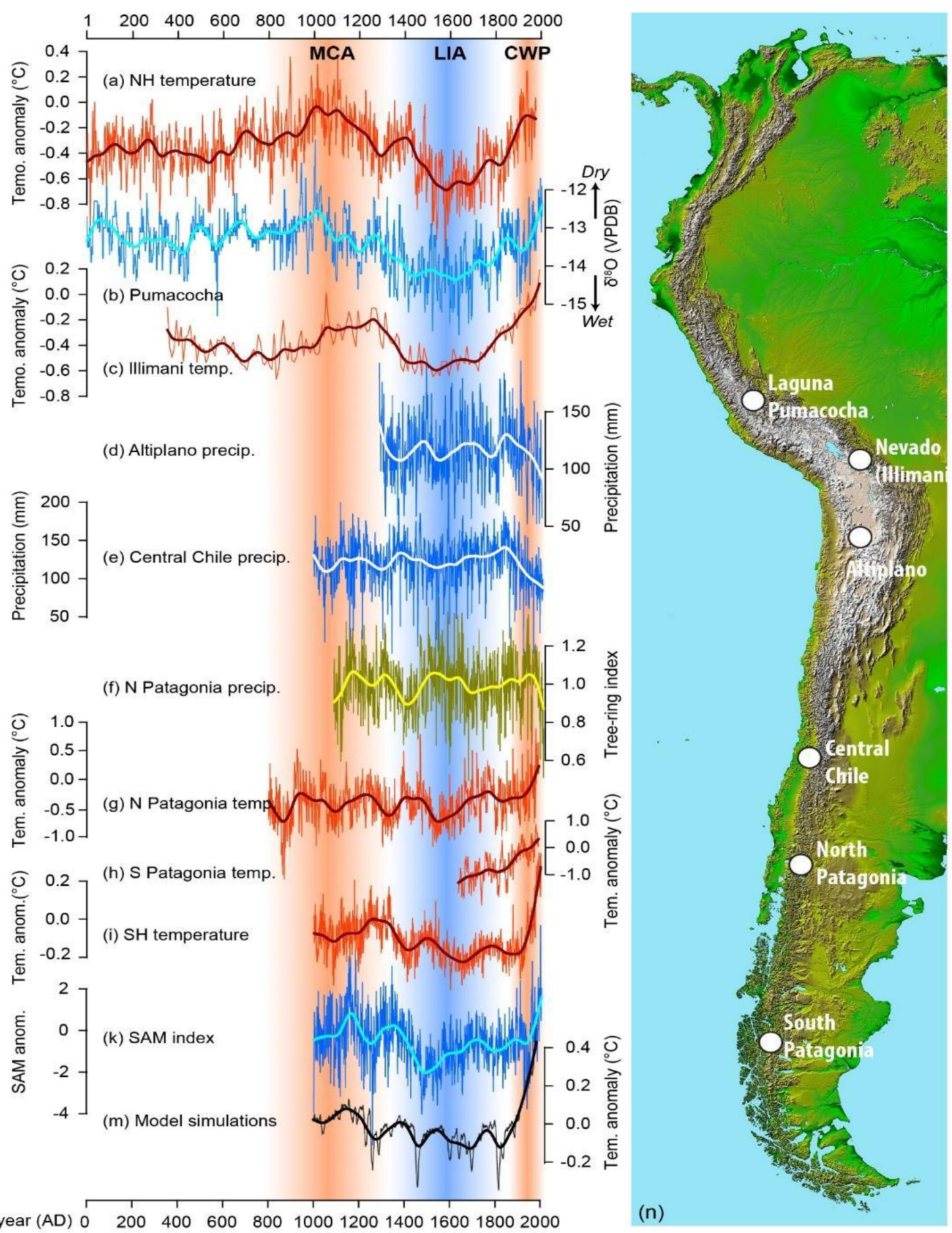

FIGURE 1 | Climatic variations along the Andes during the last 2000 years and their relationships with hemispheric and global forcings of long-term climate variability. (A) Reconstruction of $\mathrm{NH}$ temperature anomalies (Moberg et al., 2005), (B) The Pumacocha $\delta^{18} \mathrm{O}$ record of SAMS intensity (Bird et al., 2011); (C) Reconstruction of tropical South American temperature anomalies (Kellerhals et al., 2010); (D) Annual precipitation reconstruction in the South American Altiplano (Morales et al., 2012); (E) Reconstruction of winter-early summer (June-December) normalized precipitation anomalies from Central Chile (Garreaud et al., 2017); (F) Precipitation-sensitive chronology from Austrocedrus chilensis in northern Patagonia (Villalba et al., 2012); (G) Summer (December-February) temperature reconstruction in northern Patagonia (Villalba, 1990 and updates); (H) Annual temperature variations in southern Patagonia (Villalba et al., 2003); (I) Ensemble mean temperature reconstruction for the SH relative to the millennium mean (Neukom et al., 2014); (K) Summer (December-March) reconstruction of the Southern Annular Mode (Dätwyler et al., 2018); (M) Twenty-four member climate model ensemble for temperature variability in the SH (Neukom et al., 2014). To emphasize the long-term variability, all records are also shown in a smoothed version using a 128-year spline filter; (N) Map of the western part of South America showing the location of the proxy records and the geographical areas discussed in the text. 
has been the warmest interval during the last millennium in the northern Patagonian east of the Andes (Figure 1G). The records of stable isotopes from Fitzroya extending from $\mathrm{AD}$ 1800 to present, also indicate that the 20th century was warmer than the 19th century, recording the highest temperatures of the past 200 years since the mid-1970 (Lavergne et al., 2018). The lowest temperatures in the eastern sector of northern Patagonia were concurrent with the LIA in the $\mathrm{NH}$ (Figure 1A) and with the period of lowest temperatures in the $\mathrm{SH}$ over the last millennium (Figure 1I). During the MCA, reconstructed temperatures oscillated around the long-term mean (Figure 1G). Most of the long-term periods with low temperatures in northern Patagonia showed abundant precipitations (Figures 1G,F), a climatic pattern seen in current instrumental records during summer (Bianchi et al., 2016).

High-resolution reconstructions of temperature variations in southern South America $\left(47-52^{\circ} \mathrm{S}\right)$ have been based on Nothofagus pumilio tree-ring chronologies and they are limited to the past 200-400 years (Aravena et al., 2002; Villalba et al., 2003). In these records, the lowest temperatures reconstructed during the end of the LIA contrast with the period of high temperatures since the beginning of the 20th century (Figure 1H). As in northern Patagonia, temperatures from the 1970 s onward are the warmest in the last four centuries. Although current high-resolution paleoclimatic records in the region are limited in temporal coverage, a combination of radiocarbon and dendrochronological dating of in situ subfossil trunks buried by glacial deposits support the occurrence of a warmer interval before than the LIA (Masiokas et al., 2009). Trees buried by glacier advances associated with LIA suggest that forests in front of valley glaciers were established during the MCA, when temperatures in southern Patagonia were similar to or even higher than today. These records support the occurrence of cold events during the LIA preceded by warmer events concurrent with the MCA in the southern Patagonian Andes. This pattern of temperature variations is consistent with those recorded in both the NH (Figure 1A) and SH (Figure 1I) and with Southern Annular Mode (SAM) variations over the last 1000 years showing positive indices from approximately 1000 to 1400 and recently from 1900 to present (Figure 1K).

Ten degrees latitude farther south in the Andes, variations in precipitation over the last millennium have also been estimated from Austrocedrus chilensis trees at the dry steppe-forest ecotone in northern Patagonia (37-44º S; Villalba et al., 1998, 2012 and updates). Similar to the Altiplano and central Chile, the interannual variability in this precipitation-sensitive record is very high, masking somewhat the low-frequency climatic signal in the record (Figure 1F). The longest wet period from mid-15th to late17 th centuries in the past millennium was concurrent with the cold period of the LIA recorded in both the NH (Figure 1A) and the SH (Figure 1I), as well as in northern Patagonia temperature reconstruction (Figure 1G). Two prolonged dry periods at the end of the 11th century and centered on the 14th century were recorded during the MCA (Figure 1F). These two longterm dry periods have been surpassed in magnitude by the severe droughts in recent decades (Figure 1F). Indeed, northern Patagonia has showed the largest reduction in precipitation in the extratropical Andes since the mid-20th century (Quintana and Aceituno, 2012), a negative precipitation trend associated with the persistently positive increase in the SAM (Figure 1K). Consistent with the SAM influences on precipitation in northern Patagonia during the instrumental period (Garreaud et al., 2009; Villalba et al., 2012), the long-term interval with abundant precipitation during the LIA was concurrent with the most marked negative trends in SAM during the last millennium (Figure 1K; Dätwyler et al., 2018).

\section{Paleoclimate Model Simulations}

A 24-member multi-model ensemble for temperature variations during the past millennium in the $\mathrm{SH}$ (Figure 1M; Neukom et al., 2014) show some common features with proxy-based climate reconstructions. The warmest pre-industrial temperatures are simulated sometime between 1050 and 1250 preceding somewhat the phase of maximum $\mathrm{SH}$ pre-industrial warmth in the $\mathrm{SH}$ temperature reconstruction (Figure 1I; Neukom et al., 2014). Between 1300 and 1900, simulated temperatures are close to the 1000-2000 mean, periodically interrupted by shorter volcanically induced cold excursions. In contrast to the delay in industrial $\mathrm{SH}$ warming in the $\mathrm{SH}$ temperature reconstruction (Figure 1I), the climate model simulations show a mostly synchronous temperature increase after 1850 (Figure 1M). The multi-model temperature ensemble shows some similarities with the temporal evolution of the SAM (Figure 1K) during the last 1000 years, particularly during the period AD 1000-1500. However, Dätwyler et al. (2018) explicitly stated no link between their reconstructed SAM index and external forcings, suggesting that the apparent trend similarities between simulated $\mathrm{SH}$ temperatures and the reconstructed SAM may only be just coincidence. The clearest global cooling signals in response to the volcanic eruptions around years 1450 (likely Reclus volcano; Hartman et al., 2019) and 1258 (Samalas) in the ensemble models are present in the SAM reconstruction (Figure $\mathbf{1 K}$ ), recording two of the most negative indices during these volcanic eruptions.

The number of high-resolution paleoenvironmental records should be increased to achieve a comprehensive view of the long-term climatic variations over the past two millennia across the extensive and topographically complex Andes Mountains. However, the proxy indicators developed so far have initially allowed us to advance our understanding of long-term climate variability in the Andes. The seven selected natural archives shown in Figure 1, regardless of type (trees, sedimentary records, ice cores) and parameters evaluated (ring width, chemical or isotopic composition), coincide in showing that the climate during the last decades (to be discussed in the following section) along the Andes is experiencing extreme climatic conditions, many of them unprecedented in the last millennia (Figure 1).

\section{HYDROCLIMATE CHANGES IN THE ANDES OBSERVED DURING THE LAST DECADES}

Recent hydroclimate changes over the Andes are widely manifested by trends in air surface temperature, precipitation, 
glaciers area and volume, runoff and surface land cover. Here, the recent trends on hydroclimate variables in the Andes are reviewed. Cryosphere changes in the Andes are not discussed in this work. This topic is discussed by a paper in this Frontiers special issue, and by the recent Intergovernmental Panel on Climate Change (IPCC) special report on oceans and cryosphere in a changing climate (IPCC, 2019b).

\section{Air Surface Temperature Trends in the Andes}

The IPCC Fifth Assessment Report (AR5) summarized scientific literature addressing trends of air surface temperature in South America (IPCC, 2013, 2014). However, since 2012, several regional studies not assessed in the AR5 (Marengo et al., 2012a; Pabón, 2012; de los Skansi et al., 2013; Lavado-Casimiro et al., 2013; Seiler et al., 2013a,b; Carmona and Poveda, 2014; Vuille et al., 2015; Castino et al., 2016; Morán-Tejeda et al., 2016) provide updated analyses and revisit previous trend estimates over different zones in the Andes, as well as point out a number of scientific questions associated with the detected trends.

Among all studies, there is a general agreement in the rising of temperatures from different perspectives and metrics. These studies suggest an overall increase in the number of warm days and nights, as well as a decrease of cold nights and days over western South America (i.e., the Andean belt from Ecuador to Argentina). IPCC (2014) reported an increasing trend of $0.1-0.4^{\circ} \mathrm{C} /$ decade in monthly mean temperature and an overall increase of temperature extremes on tropical (North of $27^{\circ} \mathrm{S}$ ) and subtropical $\left(27^{\circ} \mathrm{S}-37^{\circ} \mathrm{S}\right)$ Andes. Over the tropical Andes minimum and maximum temperatures show a rising trend with a few exceptions in Bolivia and Peru highlands (Martínez et al., 2011). Barkhordarian et al. (2017) attributed an increase of daily maximum and minimum temperatures, especially during the December-January-February (DJF) over the north tropical Andes (North of $8^{\circ} \mathrm{S}$ ), to anthropogenic activity. In addition, over the Amazon rainforest, warming trends have reached values of 0.6$0.7^{\circ} \mathrm{C}$ over the last 40 years, suggesting 2016 as the warmest year in the region since at least 1950 (Jimenez-Muñoz et al., 2018; Marengo et al., 2018a).

A growing number of studies suggests that the rate of warming may be amplified with elevation (e.g., Rangwala and Miller, 2012; Pepin et al., 2015; Palazzi et al., 2017, 2019). Although there is not yet full agreement on this issue, the elevation-dependent warming (EDW) may have important implications for the mass balance of the high-altitude cryosphere; it can accelerate the rate of change in mountain hydrological regime, ecosystems, and biodiversity. The lack of a dense network of stations along the Andes does not allow addressing comprehensively this issue. However, Russell et al. (2017) show evidence from several reanalysis products of a regional enhancement of mid-tropospheric warming around the south tropical Andes $\left(8^{\circ} \mathrm{S}-27^{\circ} \mathrm{S}\right)$ over the past few decades that makes this region stand out as a hotspot within the broader pantropic. On the other hand, a vertical stratification of the temperature trends over recent decades has been documented by a number of regional studies for the tropical Andes and western slopes of the subtropical Andes $\left(27^{\circ} \mathrm{N}-37^{\circ} \mathrm{N}\right.$ ) (Falvey and Garreaud, 2009; Vuille et al., 2015; Burger et al., 2018). Vuille et al. (2015) and Aguilar-Lome et al. (2019) show an EDW of air and land surface temperature in the region, respectively (Figure 2 ). These studies suggest that the tropical Andes (north of $27^{\circ} \mathrm{S}$ ) have suffered a warming trend of $0.15-$ $0.2^{\circ} \mathrm{C} /$ decade above the 4000 m.a.s.l during the last four decades. Vuille et al. (2015) further suggest that future warming at higher elevations will likely enhance vertical stratification of atmospheric temperature trends, whereas in coastal locations, temperature trends will depend on changes in large-scale circulation controlling near-coastal sea surface temperature (SST), and on the state of Pacific Oscillations, such as the Pacific Decadal Oscillation (PDO).

Climate of the subtropical and extratropical Andes (South of $27^{\circ} \mathrm{S}$; Chile and Argentina) has undergone significant changes during the last century. Though the in situ data coverage from meteorological and hydrological stations is sparse over the region, several studies dealing with a variety of datasets and analysis show agreement in identifying the temperature increase as the most robust climate signal. However, these trends are not uniform all along the subtropical and extratropical Andes, but highly dependent on regional features. Masiokas et al. (2006); Rusticucci et al. (2014) and Saavedra et al. (2018) reported a sustained warming trend on both sides of the subtropical Andes $\left(27^{\circ} \mathrm{S}-37^{\circ} \mathrm{S}\right)$, especially at annual scale and during the warm season in central Chile (DJF).

Table 1 summarizes estimates of air surface temperature trends over different periods in the Andes from previous studies.

\section{Precipitation Trends in the Andes}

Trends in annual precipitation exhibit different signs across sectors in the Andes. For instance, annual precipitation trends in north tropical (north of $8^{\circ} \mathrm{S}$ ) and south tropical $\left(8^{\circ} \mathrm{S}\right.$ $27^{\circ} \mathrm{S}$ ) Andes do not show a homogeneous pattern, ranging between $-4 \% /$ decade and $+4 \% /$ decade with respect to the mean annual precipitation volume of a 30 -year period at the end of the 20th century. Even within the inter-Andean valleys of northern South America, precipitation trends have opposite signs (Pabón, 2012; Carmona and Poveda, 2014; IDEAMUNAL, 2018). In particular, precipitation has been increasing over the eastern slopes of the Andes in Colombia, Ecuador and northern Peru. For the 1964-2008 period, Martínez et al. (2011) reported decreasing trends in annual precipitation in the north tropical (north of $8^{\circ} \mathrm{S}$ ) and south tropical $\left(8^{\circ} \mathrm{S}\right.$ $27^{\circ} \mathrm{S}$ ) Andes with exception of the western cordillera of the Colombian Andes, the Ecuadorian Andes, and a few sites in the southern highlands of Peru. Martínez et al. (2011) also reported a positive trend of relative humidity in northern Ecuador and southern Colombia, and less marked positive trends over southern Peru and western Bolivia. These trends coincide with positive cloud cover trends in the northern tropical Andes during December-January-February, while a negative trend in the southern sector of the tropical Andes is observed. Barry and Seimon (2000) suggested an apparent upward shift in the orographic cloud band over this region, highlighting the 


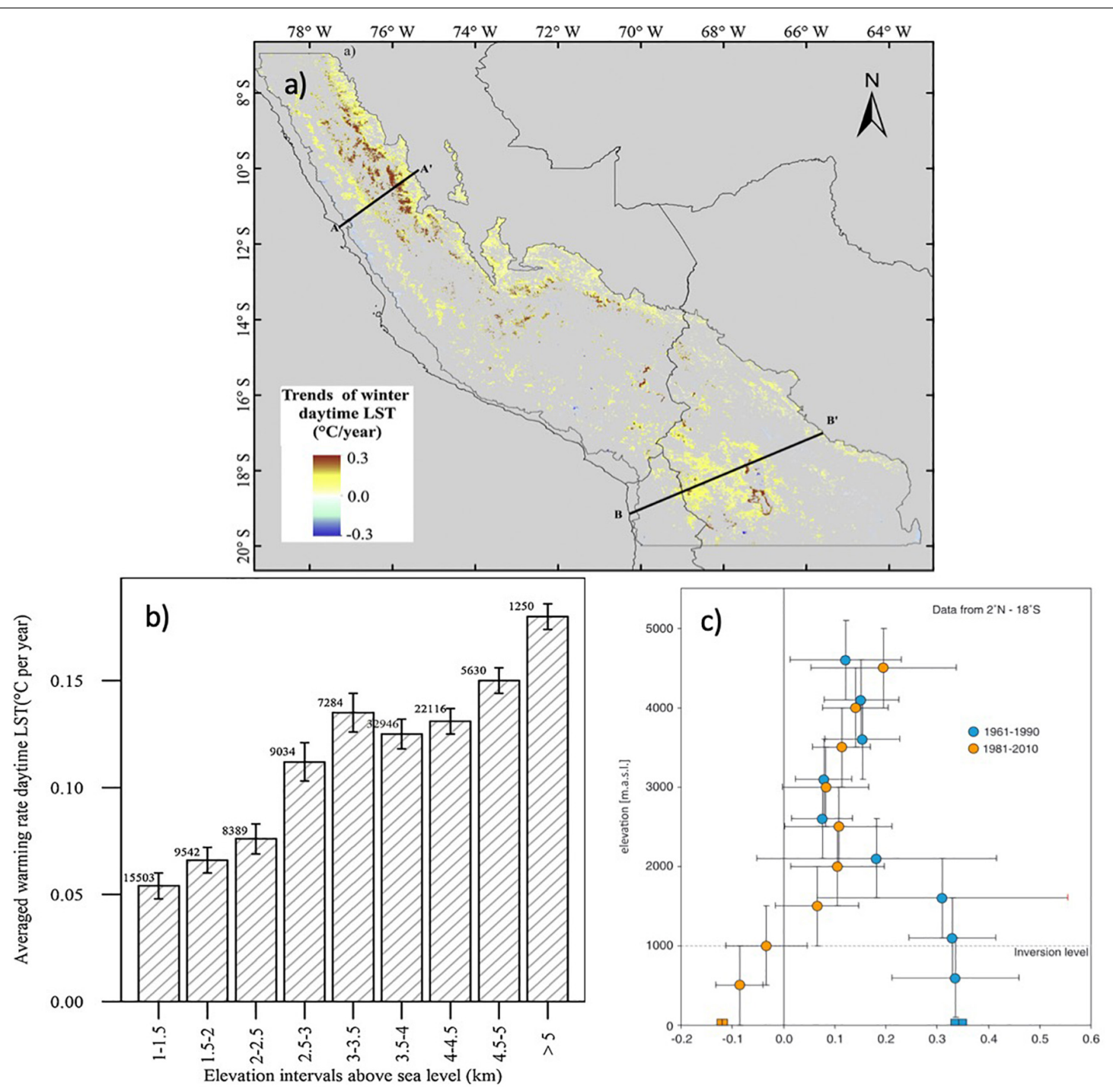

FIGURE 2 | (a) Spatial distribution of the daytime land surface temperature (LST; ${ }^{\circ} \mathrm{C} /$ year) trend in austral winter [June-July-August (JJA)] over the Andes between $7^{\circ} \mathrm{S}$ and $20^{\circ} \mathrm{S}$ for the period 2000-2017 (MODIS LST Data). Trends are significant at 95\% ( $p=0.05$ ) confidence level. (b) Averages of winter daytime LST trends at $500-\mathrm{m}$ intervals in the tropical Andes $\left(7^{\circ} \mathrm{S}-20^{\circ} \mathrm{S}\right)$. Values at the top of bars indicate the number of MODIS pixels at each elevation range. (a,b) Are adapted from Aguilar-Lome et al. (2019). (C) International Journal of Applied Earth Observation and Geoinformation. Reprinted by permission from Elsevier. (c) Air temperature trends versus altitude along the western tropical Andean slopes $\left(2^{\circ} \mathrm{N}-18^{\circ} \mathrm{S}\right)$ for the periods $1961-1990$ (blue circle) and $1981-2010$ (orange circle). Adapted from Vuille et al. (2015). (c) American Geophysical Union. Reprinted by permission from John Wiley and Sons.

importance of this vertical cloud shift supporting cloud forest and regional natural environment.

The Amazonian side of the north tropical Andes (northern and northwestern Amazon) has experienced wetter conditions since the mid-1990s, particularly during its wet season (December to May) (Espinoza et al., 2009; Gloor et al., 2013; Barichivich et al., 2018; Wang et al., 2018). Increasing rainfall intensity has been related to an enhanced convective activity over this region and the intensification of the Walker cell since the mid-1990s. Wet-day frequency (WDF) significantly increases in the northern Amazon (north of $8^{\circ} \mathrm{S}$ ), producing an estimated rainfall increase during the March-April-May (MAM) season of 17\% between 1981 and 2017 (Figure 3; Espinoza et al., 2019a). These significant changes in both WDF and rainfall in the northern Amazon have been detected since 1998. After 1998, the increase in MAM WDF and rainfall is explained by enhanced moisture flux from the tropical North Atlantic Ocean and an increase in deep convection over the northern and northwestern Amazon.

Over the central and southern Amazon, the dry-day frequency (DDF) has increased in austral winter and spring, during the 1981-2017 period, particularly for September-October-November (SON) (Espinoza et al., 2019a), which corresponds to the wet season onset in this region (Figure 3). Consistently, total rainfall in the southern Amazon during SON also shows a significant decrease of $18 \%$ during 
TABLE 1 | Trends detected in air temperature and precipitation in the Andes.

\begin{tabular}{|c|c|c|c|c|}
\hline Region & Air Temperature & Precipitation & Period Analyzed & Authors \\
\hline VNZ & & $\begin{array}{l}\text { Increase of precipitation between } \\
25 \text { and } 75 \mathrm{~mm} / \text { decade }\end{array}$ & 1950-2010 & de los Skansi et al., 2013 \\
\hline $\mathrm{COL}$ & $\begin{array}{l}\text { Increase of mean temperature } \\
\text { between } 0.1 \text { and } 0.2^{\circ} \mathrm{C} / \text { decade; } \\
\text { slight decrease in number of frost } \\
\text { days }\end{array}$ & $\begin{array}{l}\text { Decrease of precipitation in most } \\
\text { of the Colombian Andes; increase } \\
\text { in some places of the Magdalena } \\
\text { river basin slopes }\end{array}$ & 1960-2005 & Pabón, 2012 \\
\hline \multirow[t]{3}{*}{ ECU } & $\begin{array}{l}\text { Increase of maximum and } \\
\text { minimum temperatures (average } \\
\text { increase of } 0.25^{\circ} \mathrm{C} / \text { decade) }\end{array}$ & $\begin{array}{l}\text { Increase of precipitation in most } \\
\text { sites of Andes }\end{array}$ & 1966-2011 & Morán-Tejeda et al., 2016 \\
\hline & $\begin{array}{l}\text { Overall increase of number of } \\
\text { warm days and warm nights; } \\
\text { reduction of cold days and cold } \\
\text { nights }\end{array}$ & $\begin{array}{l}\text { Increase of precipitation between } \\
0.25 \text { and } 0.5 \mathrm{~mm} / \text { year }\end{array}$ & 1950-2010 & de los Skansi et al., 2013 \\
\hline & & $\begin{array}{l}\text { Decrease in rainfall over the } \\
\text { Ecuadorian-Peruvian Amazon } \\
\text { basin }\end{array}$ & $\begin{array}{l}\text { 1971-2004 (at Tamshiyacu } \\
\text { basin); 1969-2004 (at } \\
\text { Tabatinga basin) }\end{array}$ & $\begin{array}{l}\text { Espinoza et al., 2011; } \\
\text { Lavado-Casimiro et al., } 2012\end{array}$ \\
\hline \multirow{4}{*}{ PER } & & $\begin{array}{l}\text { Negative trend in precipitation in } \\
\text { central Peruvian Andes of } \\
-4 \% / \text { decade during } \\
\text { January-March }\end{array}$ & 1970-2004 & Silva et al., 2008 \\
\hline & $\begin{array}{l}\text { Overall increase of number of } \\
\text { warm days and warm nights; } \\
\text { reduction of cold days and cold } \\
\text { nights }\end{array}$ & $\begin{array}{l}\text { Slight increase of precipitation (up } \\
\text { to } 25 \mathrm{~mm} / \text { decade) at the } \\
\text { northern and a small sector at the } \\
\text { southern Peruvian Andes; } \\
\text { decrease of precipitation } \\
(25-75 \mathrm{~mm} / \text { decade) over the } \\
\text { central Peruvian Andes and close } \\
\text { to Bolivia }\end{array}$ & 1950-2010 & de los Skansi et al., 2013 \\
\hline & $\begin{array}{l}\text { Annual minimum (maximum) } \\
\text { temperature increase of } 0.18 \\
(0.16)^{\circ} \mathrm{C} / \text { decade }\end{array}$ & & 1964-2014 & Vicente-Serrano et al., 2018 \\
\hline & $\begin{array}{l}\text { In Cordillera Blanca }\left(8^{\circ} \mathrm{S}-11^{\circ} \mathrm{S}\right) \text {, } \\
\text { an increase of } 0.31^{\circ} \mathrm{C} / \text { decade } \\
\text { over } 1969-1998 \text { and a slowdown } \\
\text { in the warming to } 0.13^{\circ} \mathrm{C} / \text { decade } \\
\text { over } 1983-2012\end{array}$ & & 1969-2012 & Schauwecker et al., 2014 \\
\hline
\end{tabular}


TABLE 1 | Continued

\begin{tabular}{|c|c|c|c|c|}
\hline Region & Air Temperature & Precipitation & Period Analyzed & Authors \\
\hline & $\begin{array}{l}\text { Increase of number of warm } \\
\text { nights; decrease of number of } \\
\text { cold nights; in some places } \\
\text { decrease of warm days and } \\
\text { increase of cold days }\end{array}$ & $\begin{array}{l}\text { Decrease of precipitation } \\
\text { between } 75 \text { and } 25 \mathrm{~mm} / \text { decade } \\
\text { at the northern Bolivian Andes; } \\
\text { increase precipitation (up to } \\
25 \mathrm{~mm} / \text { decade) in some places } \\
\text { over the central Bolivian Andes }\end{array}$ & 1950-2010 & de los Skansi et al., 2013 \\
\hline & & $\begin{array}{l}\text { Decrease of annual rainfall in } \\
\text { southern Bolivian Amazon. } \\
\text { Rainfall increase in northern } \\
\text { Bolivian Amazon during } \\
\text { December-February }\end{array}$ & $1981-2018$ & Espinoza et al. (2019b) \\
\hline \multirow{4}{*}{$\mathrm{CHI}$} & & $\begin{array}{l}\text { Decrease of annual precipitation } \\
\text { about } 65 \mathrm{~mm} / \text { decade }(7.1 \%) \text { in } \\
\text { central Chile }\end{array}$ & 1979-2014 & Boisier et al., 2016 \\
\hline & & $\begin{array}{l}\text { Robust drying trend }\left(30^{\circ} \mathrm{S} \text { to }\right. \\
\left.48^{\circ} \mathrm{S}\right) \text { is:eper over } 1960-2016\end{array}$ & 1960-2016 & Boisier et al., 2018 \\
\hline & & $\begin{array}{l}\text { More drought events since the } \\
\text { second half of the twentieth } \\
\text { century }\left(30-37^{\circ} \mathrm{S}\right)\end{array}$ & $1910-2011$ & González-Reyes et al., 2017 \\
\hline & $\begin{array}{l}\text { In central and northern Chile } \\
\left(17^{\circ}-37^{\circ} \mathrm{S}\right) \text { : strong vertical } \\
\text { stratification of temperature } \\
\text { trends in the atmosphere west of } \\
\text { the Andes: a warming in the } \\
\text { Andes }\left(+0.25^{\circ} \mathrm{C} / \text { decade }\right) \text { and } \\
\text { surface cooling at coastal } \\
\text { stations }\left(-0.2^{\circ} \mathrm{C} / \text { decade }\right)\end{array}$ & & 1979-2006 & Falvey and Garreaud, 2009 \\
\hline \multirow[t]{2}{*}{ ARG } & & $\begin{array}{l}\text { Increase of annual precipitation in } \\
\text { the arid, high-elevation southern } \\
\text { Andean Plateau; decrease of } \\
\text { annual precipitation at low } \\
\text { elevations }\end{array}$ & 1979-2014 & Castino et al., 2016 \\
\hline & $\begin{array}{l}\text { Reduction of number of cold } \\
\text { days and cold nights; increase of } \\
\text { number of warm days and warm } \\
\text { nights }\end{array}$ & $\begin{array}{l}\text { Increase of precipitation in } \\
\text { northern and central Argentinian } \\
\text { Andes; decrease of precipitation } \\
\text { in the southern Argentinian Andes }\end{array}$ & $1950-2010$ & de los Skansi et al., 2013 \\
\hline
\end{tabular}

the period 1981-2017 (Espinoza et al., 2019a). In agreement, Marengo et al. (2011, 2018a) and Fu et al. (2013) show that the dry season length over the southern Amazon has increased in around 1 month since the 1970s (Figure 3), which is associated with a delay in the onset of the SAMS (Arias et al., 2015).

Rainfall trend in the south tropical Andes $\left(8^{\circ} \mathrm{S}-27^{\circ} \mathrm{S}\right)$ shows a high sensitivity with respect to the specific region and period considered (Lavado-Casimiro et al., 2012, 2013; Seiler et al., 2013a; Heidinger et al., 2018). In Bolivia, Seiler et al. (2013a) document an increase of rainfall during the 1965-1984 period, and a rainfall decrease since 1984. These results are in agreement with Espinoza et al. (2019a; 2019b) and Molina-Carpio et al. (2017), who report an increase in dry conditions in most of the Bolivian Amazon-Andean rivers since the 1980s. In the Peruvian Andes, including the Pacific coast and the Titicaca basin, no significant rainfall trends are documented (LavadoCasimiro et al., 2012; Rau et al., 2016); however, decreasing rainfall since 1970 has been reported in the central and southern Peruvian Amazon-Andes (e.g., Silva et al., 2008; Espinoza et al., 2011; Lavado-Casimiro et al., 2012; Heidinger et al., 2018). Over 
the subtropical Andes $\left(27^{\circ} \mathrm{S}-37^{\circ} \mathrm{S}\right)$, central Chile shows declining precipitation since 1970 partly associated to the variability of the PDO, although at least $25 \%$ of this decline is not explained without considering anthropogenic forcing (Boisier et al., 2016). Further analyses confirm this drying trend over central and southern Chile and its link to ozone depletion over the Antarctic (Boisier et al., 2018), affecting regional vegetation and watersheds (Garreaud et al., 2017) and forest fires intensity (Urrutia-Jalabert et al., 2018).

Over the subtropical northwestern Argentinian Andes, Castino et al. (2016) found that precipitation trends are strongly dependent on elevation: low (500 $\mathrm{m}$ above sea level -m.a.s.l.), intermediate (500-3000 m), and high-elevation (>30000 m.a.s.l) areas respond differently to changing climate conditions, and the transition zone between low and intermediate elevations is characterized by the most significant positive annual rainfall trends since 1950. At low elevations areas, generalized decreasing trends are observed.

Table 1 summarizes estimates of precipitation trends over the Andes identified from several studies based on different periods and datasets.

\section{Surface Hydrology Trends in the Andes}

The sparse and short period of observations of hydrological networks in the Andes hinder the study of hydrological variability and trends in the region. It also hampers hydrological modeling and regional studies (Buytaert and Beven, 2009; Paiva et al., 2011; Zulkafli et al., 2014; Wongchuig-Correa et al., 2017; Zubieta et al., 2017). At the same time, airborne measurement such as satellite-derived precipitation data has large uncertainties in this region, and remote sensing water level data is almost impossible to obtain from the narrow rivers and valleys present in the region. As a consequence, hydrological modeling has been used to extend historical records, simulate land-use and future climate change scenarios and get a better understanding of hydrological processes in the Andes (Buytaert and Beven, 2009; Paiva et al., 2013; Zulkafli et al., 2016; Olsson et al., 2017; Zubieta et al., 2017). Thus, hydrological modeling studies in the region are foreseen to increase.

Despite data shortcomings, several studies based on data from measurements have provided further evidence of hydroclimate changes in the Andes. Carmona and Poveda (2014) found that series of monthly mean river discharge in the tropical Andes of Colombia exhibit significant decreasing trends, although the signal in monthly precipitation records is mixed. LavadoCasimiro et al. (2012) found no significant trends on mean annual discharge in the western Peruvian Andes and Titicaca Lake tributaries in the northern Altiplano during the 1969-2004 period. Annual river runoff in the western Andes of Colombia, Ecuador, and Chile appeared to increase significantly (Mernild et al., 2018). In the Pauto basin (Ecuador) over the tropical Andes, Mora et al. (2014), found increasing trends in maximum flows and decreasing trends in minimum flows. Espinoza et al. (2011, 2013), Zulkafli et al. (2016); Molina-Carpio et al. (2017) and Wongchuig-Correa et al. (2017) suggest an increasing frequency of droughts and floods in the Andean Amazon region. In the Andes-Amazon region, studies on different specific regions have found diverging trends in river discharge (generally since the 1970s or 1980s). In general, these studies show decreasing discharge trends in the southern Amazon-Andes region (South of Peru and Bolivia) and increased trend in the north (Espinoza et al., 2009; Lavado-Casimiro et al., 2012; Molina-Carpio et al., 2017; Wongchuig-Correa et al., 2017; Ronchail et al., 2018). Some of these changes are associated to both Pacific and Atlantic SST anomalies and atmospheric moisture transport anomalies from the tropical Atlantic into the Amazon basin. In addition, the superposition of northern with Andean western and southern tributaries flood waves have been observed in several extreme floods in this region (Marengo et al., 2012b; Espinoza et al., 2013; Ovando et al., 2016).

The Amazonian side of the north tropical Andes (northern and northwestern Amazon) has experienced an increase in discharge of the northern tributaries of the Amazon River, especially during the period December-May (Espinoza et al., 2009; Gloor et al., 2013; Marengo and Espinoza, 2016; Barichivich et al., 2018), associated with increases of rainfall (see section "Precipitation Trends in the Andes"). Other authors document recent changes in the timing of the annual hydrological cycle in this region. For instance, Ronchail et al. (2018) found a trend to delayed endings and longer duration of the low-water period at Tamshiyacu on the upper Amazon River, as well as a more abruptly ending of the flood recession in this region. Rainfall intensification over the northern Amazon after 1998 (see section "Precipitation Trends in the Andes") has produced a major frequency of extreme floods, as recently confirmed by Barichivich et al. (2018), who showed that flood frequency of the Amazon River during the 1903-2015 period has experienced a significant fivefold increase from roughly one flood every 20 years during the first half of the 20th century to one about every 4 years from the 2000s onward (Figure 3). In the Argentinian Andes, Castino et al. (2016) found statistically significant increasing trends in river discharge during the 1940-2015 period, documenting an intensification of the hydrological cycle during this period.

Evidence of hydrological changes are also observed in the subtropical and extratropical Andes as changes of snow cover and glacier extension. The robust pattern of positive trends found in temperature records, together with the generalized recession of glaciers observed in the region, suggest that significant changes in climate have already impacted glacier mass balances in the subtropical and extratropical Andes. Changes in temperature and precipitation are the main drivers of changes in snowpack, which may have a strong socioeconomic impact in the region. In fact, Peru, Bolivia, Chile, and Argentina depend on snow and/or glaciers melt for water supply due to short rainy seasons (Masiokas et al., 2010; Peduzzi et al., 2010; Rabatel et al., 2013). Studies focused on assessing trends in snowpack coverage provide contradictory results, mainly owing to the quality and quantity of snow data. Masiokas et al. (2006) reported no significant trends of snow cover for the period 1951-2004 over the subtropical Andes (from $27^{\circ} \mathrm{S}$ to $37^{\circ} \mathrm{S}$ ) while Saavedra et al. (2018) revealed a significant negative trend of snow cover between $29^{\circ} \mathrm{S}$ and $36^{\circ} \mathrm{S}$ during the period 2000-2016, being this decrease even more pronounced on the eastern side of the Andes. The relevance of identifying trends on snowpack characteristics is clear due to 

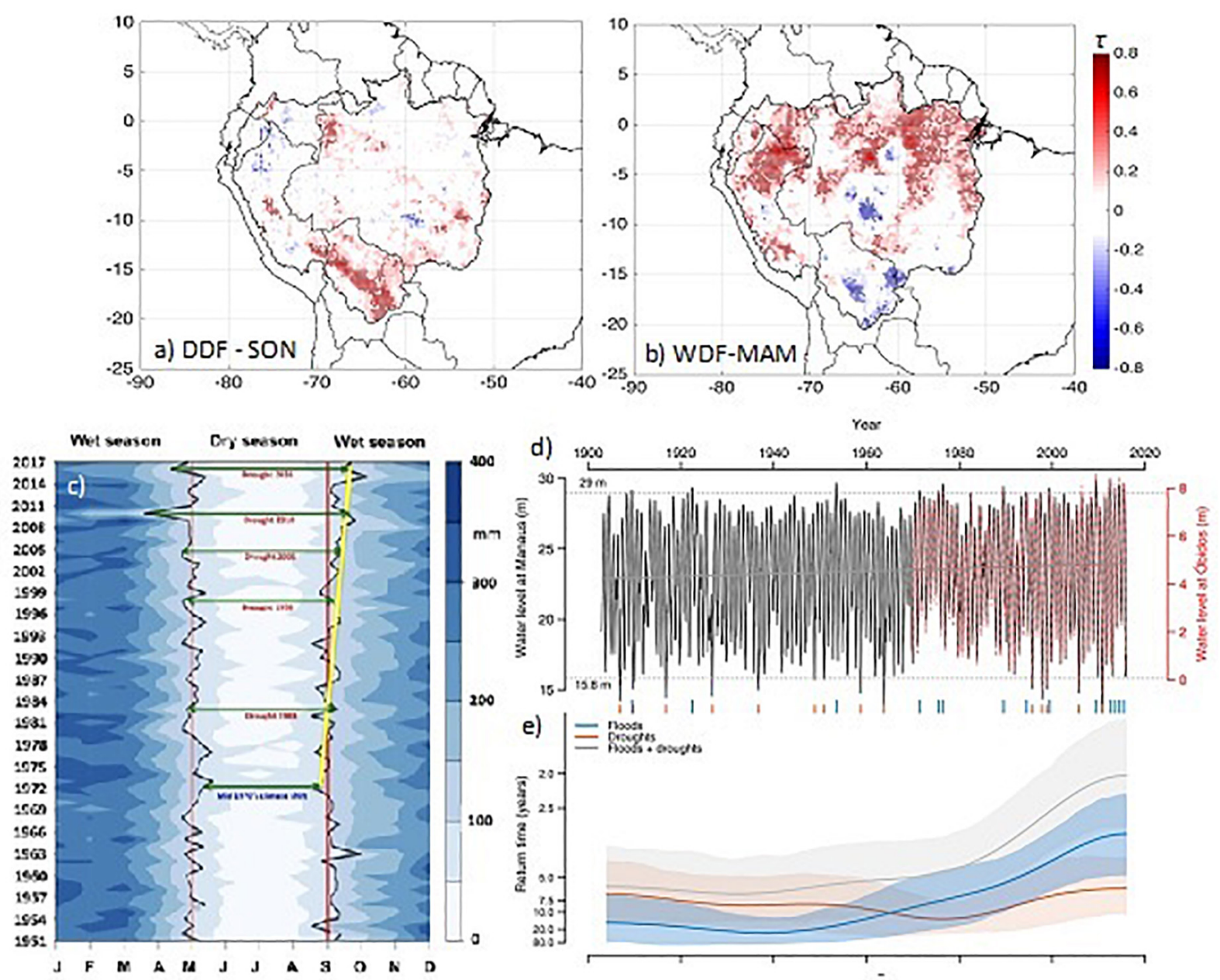

FIGURE 3 | Spatial distribution of Kendall coefficient values $(p<0.05$ are indicated with a dark dot) showing the trend for: (A) $1981-2017$ DDF during SON season and (B) 1981-2017 WDF during MAM season. DDF (WDF) are defined as days with rainfall $<1 \mathrm{~mm}$ (>10 mm). Adapted from Espinoza et al. (2019a). () Climate Dynamics. Reprinted by permission from Springer Nature. (C) Hovmoller diagram showing monthly rainfall (1951 to 2017) for southern Amazonia (mm/month). The isoline of $100 \mathrm{~mm} / \mathrm{month}$ is an indicator of dry months in the region (Sombroek, 2001). Drought years are indicated with green lines. Red lines show the average onset and retreat of the rainy season [Adapted from Marengo et al. (2011) and updated to 2017 in Marengo et al. (2018b). () American Geophysical Union. Used with permission]. Yellow line shows the trend to a longer dry season after the mid 1970's climate shift. (D) Daily water level of Negro River at Manaus (black; 1903-2015) and Amazon River at Óbidos (red; 1968-2015). The horizontal dotted lines denote the thresholds used to define drought (15.8 m) and flood (29.0 m) events from the Negro River daily water level data. The resulting events are indicated by orange (droughts) and blue (floods) vertical ticks at the bottom of the panel. (E) Time-varying frequency of the identified droughts and floods between 1903 and 2015. Adapted from Barichivich et al. (2018). CC licence. ( $)$ American Association for the Advancement of Science.

its influence on river discharges. However, more extended data records are still needed to provide fully supported evidence of trends in snow pack coverage in the region.

Several studies on monthly and annual mean discharge in the Andes show divergent trends (or no trends at all) and uncertainty is still large. The complexity of hydrological processes along the region, differences in records length, contrasting hydroclimatic variability between regions and the impact of man-induced changes (see section "Vegetation Cover and Land Use Change in the Andes and Its Effect on Regional hydroclimatology") are possible explanations for these divergent trends. For instance, Marengo et al. (1998) identified decreasing trends of minimum flows during the 20th century in the northern Pacific coast of Peru associated to increased water abstraction for irrigation and water supply (Rau et al., 2016). In the Rimac River (the main source of fresh water for Lima city), regulation or hydraulic diversion projects developed in the basin since the 1960s produced significant changes in the hydrological regime. The annual minimum flows increased by $35 \%$ while maximum flows decreased by $29 \%$ after the regulation data (Vega-Jácome et al., 2017). Souvignet et al. (2012) identified contrasting short and long-term discharge trends in the "Norte Chico" region of Chile $\left(29-32^{\circ} \mathrm{S}\right)$. Along the Desaguadero River and Poopo Lake basins in the central Altiplano, a decreasing discharge trend has been identified over the 1966-2012 period (Satgé et al., 2017), associated to increasing 
water diversion and transfer, having climate variability as a secondary cause.

Further south, the rivers originating in the Andes between $18^{\circ}$ and $55^{\circ} \mathrm{S}$ also constitute a crucial natural resource and support numerous ecosystems, human populations and a large number of socio-economic activities throughout Chile, western Argentina and southwestern Bolivia. Masiokas et al. (2019) compiled an extensive database of mean monthly streamflow records from these countries to identify the areas with common patterns of hydroclimatic variability during the instrumental era (early 20th century - present). Their results indicate that about $75 \%$ of the total variance in the mean annual (April-March) series can be explained by only eight spatially coherent patterns of variations (Figure 4A). In the central Andes of Chile and Argentina, the Norte Chico region in Chile, and the northwestern portion of Patagonia, river flows show marked negative trends that culminate in the severe droughts that these regions have been experiencing since 2009-2010. On the contrary, the river flows in northwestern Argentina and southern Bolivia, southern Patagonia (Santa Cruz river), and Tierra del Fuego show positive trends with above-average values in the last decades (Figure 4). The ENSO phenomenon in the tropical Pacific can be used to predict between $20 \%$ and $45 \%$ of the variations observed in the annual streamflows of the Andean basins located between $28^{\circ}$ and $46^{\circ} \mathrm{S}$. Other large-scale ocean atmospheric indices, such as the SAM or the PDO, also show associations with Andean flows, but their predictive power is weaker than that detected with the El Niño indicators (Masiokas et al., 2019).

\section{Vegetation Cover and Land Use Change in the Andes and Its Effect on Regional Hydroclimatology}

The surface land cover of the Andes, a crucial element in water balance, energy budget and climate, has been modified by humans since the beginning of their settlement in high- and midaltitudes to accomplish their primary needs: shelter, food, and energy. This environmental transformation has been happening during the Holocene (Young, 2009), but became more intense during the last millennium, accelerating about 500 years ago. Currently, diverse ways of land use continue actively producing changes with strong effects on biodiversity, soil dynamics, climate, water resources availability, and hydroclimate extremes. According to Salazar et al. (2015), 3.6 million $\mathrm{km}^{2}$ of the original natural vegetation cover in non-Amazonian South America (the Andes is a large part of this region) were converted into other types of land use, which is about four times larger than the historical Amazon deforestation. In contrast, land use and land cover (LULC) change processes in non-Amazonian regions have been less studied (Salazar et al., 2015).

Several studies have been conducted in the last decades in order to improve our current knowledge about LULC change dynamics and drivers in the Andes (Etter et al., 2008; Armenteras et al., 2011; Rodriguez-Eraso et al., 2013; Salazar et al., 2015). Rodriguez-Eraso et al. (2013) suggest that cropland, pasture, and secondary vegetation over the north tropical Andes (north of $8^{\circ} \mathrm{S}$ ) showed systematic transitions, changing from a traditional land use to pasture in 1980-2000 period. These authors also note a high spatial variability of transition trends in the region, controlled mainly by attractors and biophysical features. The AR5 (IPCC, 2014), and the Special Report IPCC (2019a) notes that at least for the tropical Andes, the responsible forces of LULC change are deforestation, agriculture, cattle ranching, and gold mining (IPCC, 2014, 2019a), although other socio-political dynamics play important roles in this process (Diaz et al., 2011; Hoffman et al., 2018; Salazar A. et al., 2018).

Celeri and Feyen (2009) explored the hydroclimatic effect of LULC changes in the Andes and established a climatedependence of conversion from a given land cover to another (for instance, from forest to pastures; from forest to crops; from pastures to crops). Aide et al. (2019) evaluated the change in the distribution of woody vegetation in the tropical Andes for the 2001-2014 period using Moderate Resolution Imaging Spectroradiometer (MODIS) satellite data (250 m pixel resolution) (Figure 5). These authors estimated an overall net gain of $(\sim 500,000$ ha in woody vegetation. Forest loss dominated the 1,000-1,499 $\mathrm{m}$ elevation zone and forest gain dominated above 1,500 m.a.s.l. Forest loss at lower elevations is related to transition from forest to pastures and croplands, while forest gain in abandoned pastures and cropland dominate in midelevation areas.

Changes of land cover modify surface radiative properties (albedo and absorption), inducing an effect on surface radiation balance; consequently, LULC changes produce changes in mean surface temperature. Furthermore, LULC changes also have effects on soil-vegetation interactions, which further modifies the hydrological cycle (Bonan et al., 2012). In some cases, for example in transitions from forest to pasture, LULC changes are associated with increasing surface temperature and decreasing soil moisture, precipitation and cloudiness. By contrast, transitions from pastures to coffee crops reduce mean air surface temperature (Figure 6) and increase precipitation (Carvajal-Vanegas and Pabón-Caicedo, 2014). These regional effects of LULC change on local hydroclimate may smooth or enhance the signal of global climate change, which result in different impacts on water and energy fluxes as well as on the whole regional environment.

Deforestation has a direct effect on hydrological cycle and energy budget, since forest loss modifies land cover and subsequently hydrological and radiative properties of the soil-vegetation interface. Different studies have addressed deforestation in the Andes at diverse scales. Schoolmeester et al. (2016) compared deforestation rates during two periods (20002005 and 2006-2010), finding rate reductions in some Andean countries (Bolivia, Ecuador and Venezuela) and increases in others (Peru and Colombia), although forest loss occurred over the entire region during the overall period of 20002014. Later, Armenteras et al. (2017) summarized 369 papers issued within a recent 25 years period and analyzed information with a standardized deforestation rate index in the Andes for tropical mountain forest, subtropical dry forest and subtropical temperate and mixed forests. Their results suggest a high rate of deforestation in the subtropical and extratropical Andes (Chile and Argentina), followed by the tropical Andes (Bolivia, Ecuador, Colombia, and Peru). Deforestation rates vary in the considered 

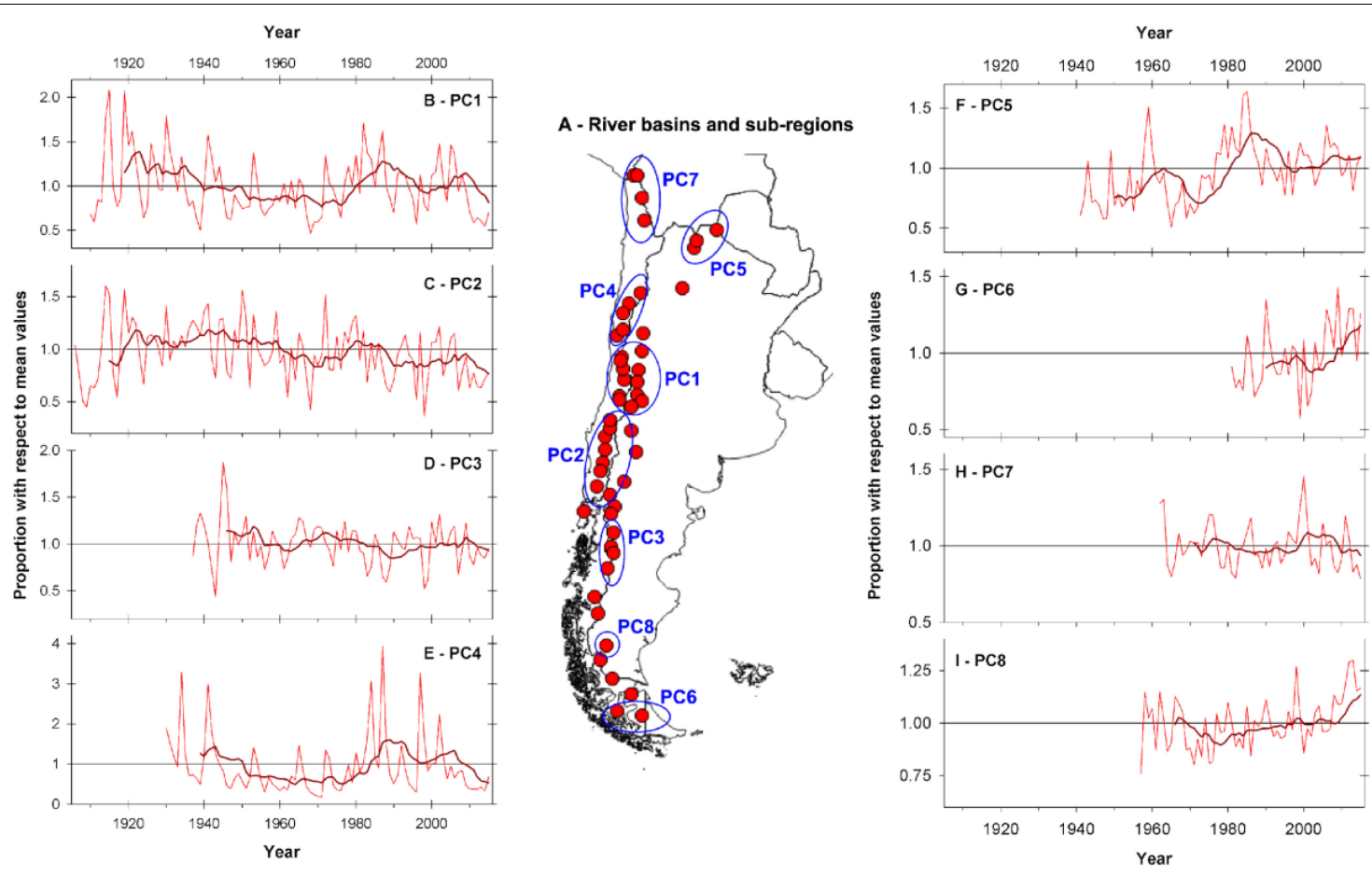

FIGURE 4 | (A) Map showing the location of the selected river basins used to identify the main regional patterns of streamflow variations in the subtropical and extratropical Andes (18-55 S). (B) Mean annual (April-March) regionally averaged streamflow record for the PC1 sub-region (thin red line). Ten-year moving averages (thick red line) are also shown to highlight the lower frequency variations in this record. (C-I) Same as (B), but for PC2 trough PC8, respectively. See Masiokas et al. (2019) for details.

period, depending on the geophysical and socioeconomic drivers in each country. Furthermore, Armenteras et al. (2017) highlight the convenience of addressing the particular features of each type of forest (dry forest, low-altitude forest, etc.), and not only those related to the main cover forest, in order to assess different analysis regarding water resources as well as hydrological cycle modeling.

Deforestation is one factor that conduces to land degradation (soil loss by water/wind erosion, soil salinization or acidification, soil compaction and drainage suppression), aridization of extended areas, advance of dunes or arid environments (desertification), biological degradation, soil pollution, and landslides, processes that have effect on regional hydroclimate. Several studies have suggested land/soil degradation is related to different causes in different areas along the Andes (e.g., Sayago and Collantes (2016) for Argentina; Preston (2016) for Bolivia; Metternicht and Zinck (2016) and Hugo (2008) for Argentina, Chile, Bolivia, Peru, Ecuador, Colombia, and Venezuela).

At a local scale, deforestation has been related to an increase of the magnitude of floods and droughts (Farley et al., 2005). Bare soils favor runoff, increasing flow velocities and reducing the time for water getting the basin outlet, thus increasing the occurrence and magnitude of peak discharges. On the other side, deforestation reduces infiltration, as well as surface and groundwater storage, leading to the reduction of base flows. These effects are particularly strong in mountain regions and have been extensively modeled (Buytaert and Beven, 2009).
The impacts of forest loss are not limited to areas where land cover changes occur but have a regional influence through atmospheric circulation mechanisms, for instance over the Andes and the Atlantic Ocean (i.e., Boers et al., 2017; Agudelo et al., 2019; Molina et al., 2019). For instance, the Amazon basin provides the Andean region with substantial contributions of water vapor (Sakamoto et al., 2011; Arias et al., 2015; Hoyos et al., 2017, 2018; Salazar J. F. et al., 2018), therefore vegetation changes in the Amazon rainforest modifies atmospheric moisture transport and hydroclimate in the Andes (Builes-Jaramillo et al., 2017; Agudelo et al., 2019; Molina et al., 2019). In this sense, vegetation-atmosphere feedbacks could play a crucial role in future precipitation over the Andes region.

Soil erosion is an immediate effect of deforestation in the Andean slopes. Human-induced soil erosion reduces soil productivity, compromises freshwater ecosystem services and drives geomorphic and ecological change in rivers and floodplains. By combining observations and modeling, Restrepo et al. (2015) estimated that erosion rates within the Magdalena drainage basin in Colombia have increased 33\% between 1972 and 2010, increasing the river's sediment load by $44 \mathrm{Mty}^{-1}$. Much of that river catchment (79\%) is under severe erosional conditions due in part to the clearance of more than $70 \%$ natural forest between 1980 and 2010. It has been estimated that $9 \%$ of the sediment load in the Magdalena River basin is due to deforestation and $482 \mathrm{Mt}$ of sediments was produced due to forest clearance over the last three decades. Extreme 


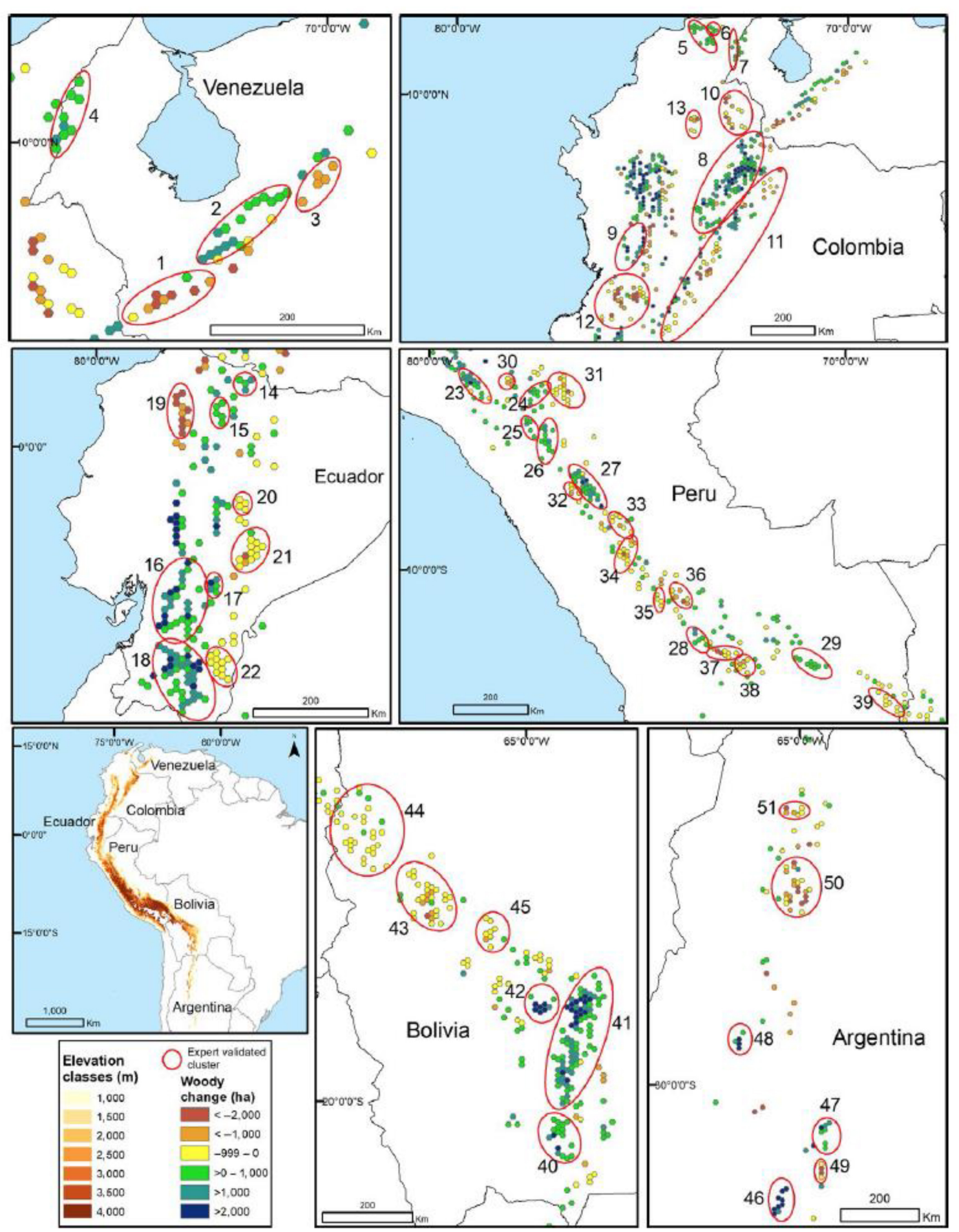

FIGURE 5 | Distribution of elevation classes within the tropical and subtropical Andes and hexagons with a significant 14-year linear increase or decrease in woody vegetation in each country. From Aide et al. (2019).

climate events play also a major role in the production of sediments, such is the case of El Niño events in the Pacific coast of Peru and Ecuador (Morera et al., 2017). The Andean cordillera provides more than $90 \%$ of the total of the sediment load observed in the Amazon Basin, with a major contribution from southwestern rivers such as Ucayali and particularly the Madeira River, which accounts for nearly $50 \%$ of the total sediment transported into the 

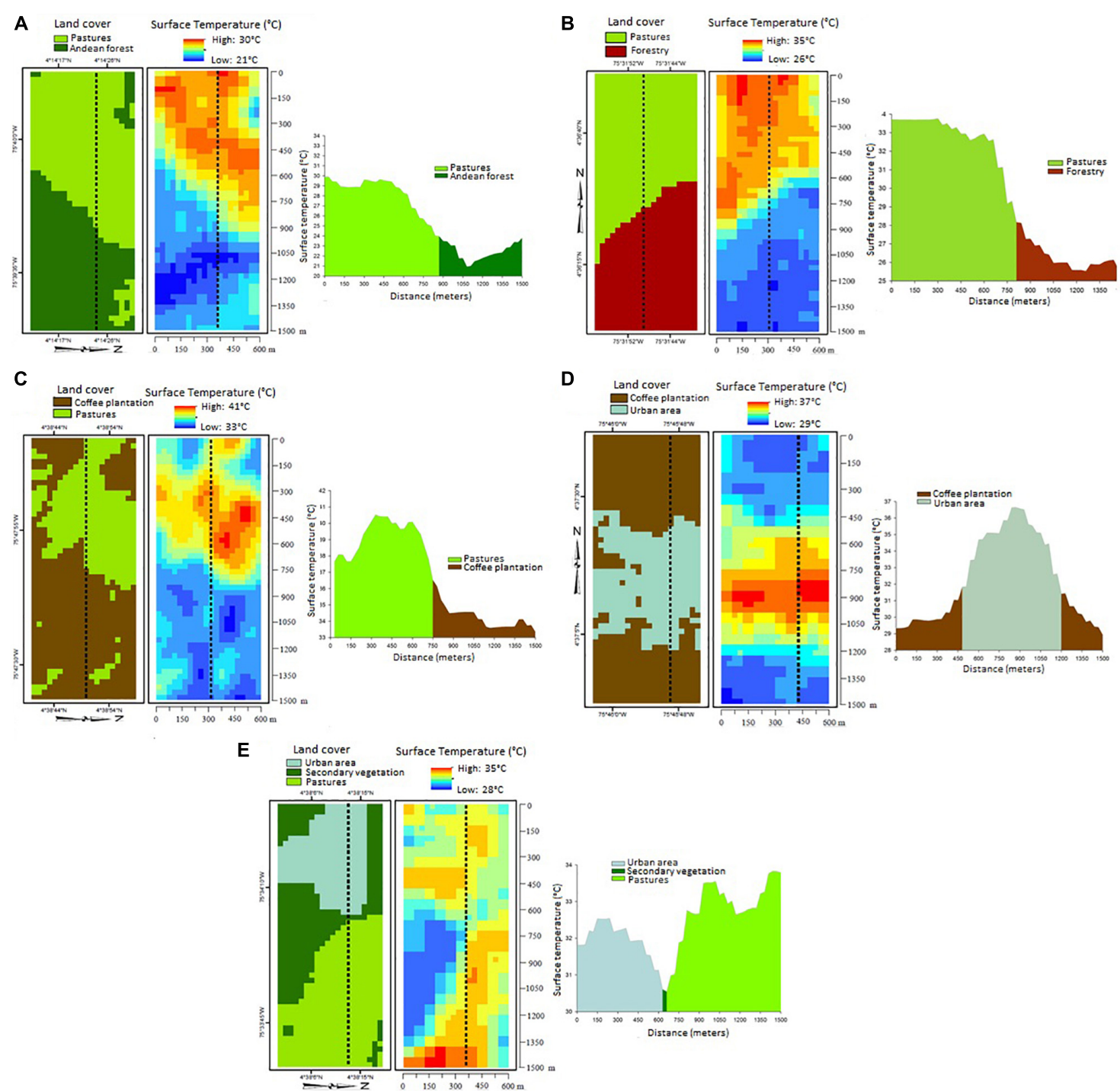

FIGURE 6 | Types of land use and land cover (left) and profiles of surface temperature (right) along the dark dotted line. Note the temperature differences between land use transitions: (A) pastures - natural Andean forest; (B) pastures - forestry; (C) coffee plantations - pastures; (D) coffee - urban area; (E) urban area secondary vegetation - pastures. Adapted from Carvajal-Vanegas and Pabón-Caicedo (2014).

Amazon system (Armijos et al., 2013; Santini et al., 2015; Vauchel et al., 2017).

Although deforestation has impacts on water cycle, it has been established that inadequate forestation may also have negative effects on water availability since some exotic tree plantations and a few native species are high-water consumers and may reduce downstream runoff supply (Balthazar et al., 2015; Bonnesoeur et al., 2019). Most of Andean countries have developed several projects regarding restoring vegetation cover and the re-establishment of ecosystem services like water supply, by using alien species (eucalyptus and pine, for example), reducing runoff and water availability. These findings, besides the practical application they may have in planning and environmental management, highlight the importance to take into account details of forest composition, in the sense of considering the role of specific tree species in water budget quantification and hydrological cycle studies.

\section{PROJECTED CHANGES IN THE ANDES DURING THE 21ST CENTURY}

\section{Temperature and Precipitation Projections From CMIP3/CMIP5 Models and Associated Uncertainties}

Coupled Atmosphere Ocean General Circulation Models (AOGCMs) and Earth System Models (ESMs) (referred hereafter to as Global Climate Models - GCMs) are the main tool for projecting future climate changes. Multi-model ensembles from 
coordinated GCMs experiments such as the Coupled Model Intercomparison Projects (CMIP3 and CMIP5) (Meehl et al., 2007; Taylor et al., 2012) have become indispensable for assessing future changes in climate at global and large regional scale and for quantifying their uncertainties. Figure 7 shows the change of precipitation and air surface temperature in South America projected by the end of the 21st century (2071-2100) under the high emission scenario RCP8.5, considering an ensemble mean of 48 CMIP 5 models.

There is a general agreement among the models on the warming over the Andes, which exhibits the lowest values over extratropical latitudes (less than $3^{\circ} \mathrm{C}$ ) and the highest values (up to $5^{\circ} \mathrm{C}$ ) over the central region (Figure $7 \mathbf{B}$ ). The latter is associated with the largest warming over the continent projected for the Amazon river basin (Blázquez and Nuñez, 2013), especially during the dry and dry-to-wet transition seasons (Figure 7B). The projected changes in precipitation are associated with large uncertainties (Figure 7A). The only Andean region where the CMIP5 models agree on the sign of future changes is central Chile, in the subtropical Andes (Figure 7A; $\mathrm{SON})$. As mentioned in section "Precipitation Trends in the Andes," in this region, the large-scale regional drying has been already evidenced as an emerging anthropogenic signal from a background observed variability (Boisier et al., 2016). The drying is projected to pursue in the future (Zazulie et al., 2017) in association with the positive SAM-like circulation change in summer caused by stratospheric ozone depletion which amplifies the effect of the same sigh driven by the greenhouse gas forcing in all seasons (Boisier et al., 2018).

Despite rather low confidence in the CMIP3/CMIP5 ensemble mean projections of precipitation over the tropical northern and southern Andes, some consensus can be found in the literature regarding future changes. Schoolmeester et al. (2016) summarized findings by Vuille et al. (2008) and Magrin et al. (2014) for the tropical Andes, and suggest that the northwestern region of Colombia, Ecuador and Peru will experience more precipitation than that observed in the present climate, while a decrease of precipitation is expected in the northeastern Andes of Venezuela and Colombia, Southern Peru, and Bolivia. A longer dry season is expected over the southern Amazonian Andes (Fu et al., 2013; Guimberteau et al., 2013; Boisier et al., 2015). The Altiplano region will exhibit a strong precipitation decline driven by an increasing westerly flow over the Central Andes (Minvielle and Garreaud, 2011; Thibeault et al., 2012; Neukom et al., 2015). In particular, under the assumption of a stable and linear relationship between precipitation and upper level zonal wind, Neukom et al. (2015) suggest a precipitation decrease of 19-33\% for 2071-2100 relative to present-day conditions (RCP8.5).

Due to the coarse spatial resolution of CMIP5 models, projections for the Andes give a generalized picture of changes over extended areas. Within these areas, different sub-regional expressions of climate variability and change may occur and then the area average may not be representative of the actual changes, which may show opposite signals between regions, as evidenced from the recent observed trends (see sections "Air Surface Temperature Trends in the Andes" and "Precipitation Trends in the Andes"). As an example, Figure 8 illustrates the regional topography of Uyuni Salt Flats (Bolivia), located at heights between 3650 and 5000 meters over a $2 \times 2$ degree area $\left(19-21^{\circ} \mathrm{S}, 69-67^{\circ} \mathrm{W}\right)$. Note that the typical resolution of atmospheric components in CMIP5 models is about $1.5^{\circ}$ (Haarsma et al., 2016). By consequence, the maximum height of the plateau in CMIP5 models is 4000 m.a.s.l. Analysis of such region in a GCMs ensemble is a complex task because of different representations of the mountains among the models. Indeed, the Andes produce a huge disturbance of the atmospheric circulation over South America, which organizes particular climates over inward and leeward sides of the range. Since simulated climate has strong dependence on the topographical height assigned to the grid points representing the mountains, spatial distribution of particular climates may strongly differ among models. One possible way to circumvent these limitations, is based on the methodology proposed in Fita et al. (2019), in which an objective classification of the simulated domain is performed by slices, based on three criteria: latitudinal bands, topographical height, and western or eastern side of the mountain range. One of the other advantages of the technique is that no additional interpolation is required.

Taking the example of the $2 \times 2$ degree box over Uyuni Salt Flats and an ensemble of 25 CMIP5 models (under the RCP8.5 scenario), Figure 9 shows the precipitation and 2-m maximum and minimum air temperature in the present climate and their future changes for different slices defined by given altitude and mountain range face (uphill, peak and downhill). Therefore, Figure 9 do not display gradients but integrate information from different sub-ensembles that have been built clustering models according to a dynamical-robustness criteria. Temperature is projected to increase everywhere over the Uyuni box with differences in intensity between changes for maximum and minimum temperature, as well as between the mountains range faces, and between altitudinal zones. Projections for precipitation show negative change, except for the uphill slice at a height of about 3500 m.a.s.l, where positive changes are projected according to the five models that resolve this altitude. It is worth noting that even the detailed analysis of future projections proposed by Fita et al. (2019) that takes into account the geographical specificities of the Andean region, suggests generally a large dispersion between models in terms of future changes in precipitation.

In general, large uncertainties in model projections of precipitation over the Andes are associated with large errors in representations of regional precipitation and their controlling processes. Indeed, whereas CMIP5 models simulate relatively well the near-surface air temperature in different regions of the Andes (Zazulie et al., 2017, 2018), they generally fail in simulating regional precipitation. Sierra et al. $(2015,2017)$ and BonillaOvallos and Mesa (2017) question the ability of the CMIP5 models to represent precipitation and its seasonal cycle in the northern tropical Andes (North of $8^{\circ} \mathrm{S}$ ). Fu et al. (2013) found large models errors in simulating the dry season length over the Southern Amazon basin and linked them to remotely driven errors in local convective inhibition energy in austral winter and to a general underestimation of the variability in the latitudinal position of the subtropical jet. Zazulie et al. $(2017,2018)$ show 

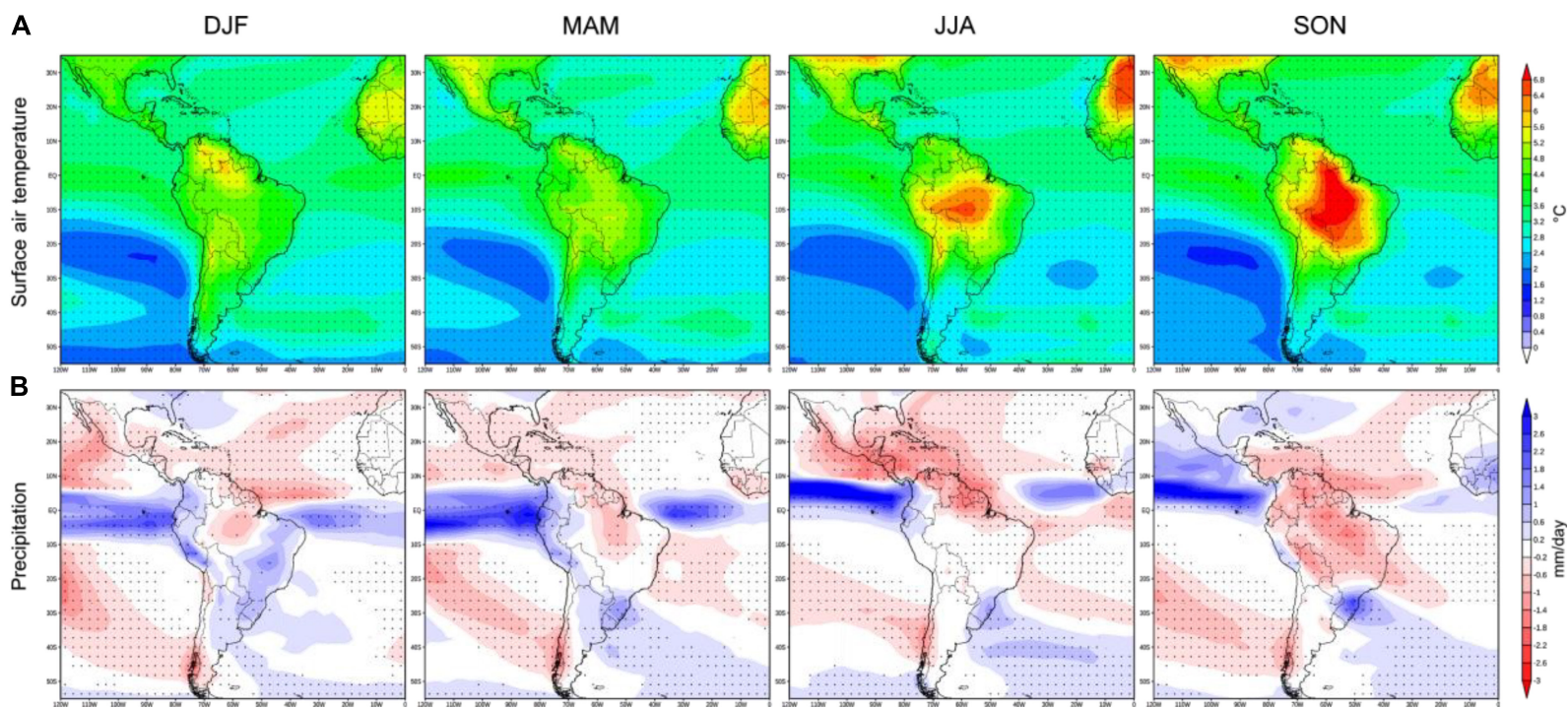

FIGURE 7 | Ensemble mean projected changes of $\mathbf{( A )}$ air surface temperature (in ${ }^{\circ} \mathrm{C}$ ) and $\mathbf{( B )}$ precipitation (in mm/day) in South America. Change is estimated as the difference between the RCP8.5 projection by the end of the 21 st century (2071-2100) and the historical simulation by the end of the 20th century (1971-2000). Ensemble mean is obtained considering 48 CMIP5 models. Dots indicate an agreement in the sign of the projected change among $80 \%$ or more of the models.

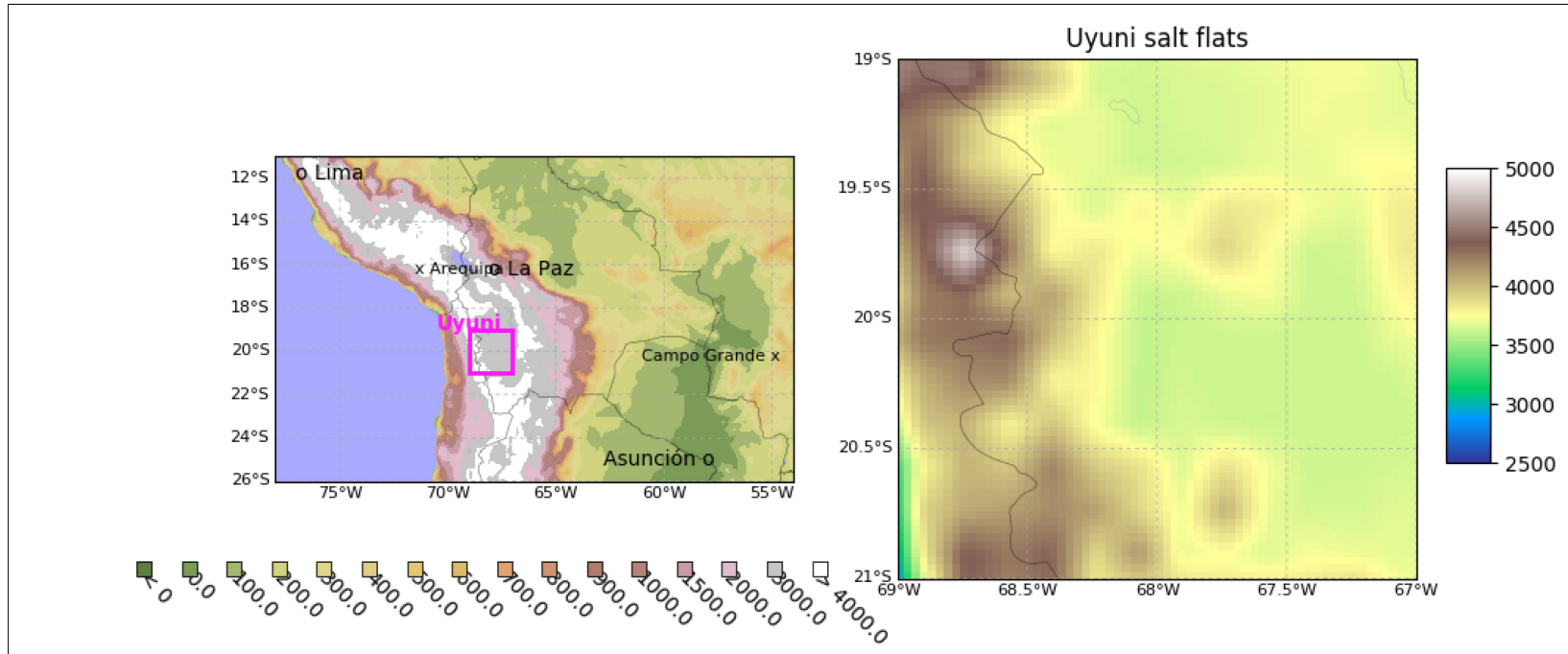

FIGURE 8 | The Uyuni Salt Flats geographical location in Potosi, Bolivia (left). $1-\mathrm{km}$ resolution map of topography (meters) in a $2^{\circ} \times 2^{\circ}$ box, shows Uyuni region as represented in CMIP5 models (right).

that the models have deficiencies in reproducing precipitation over the subtropical Andes of Chile and Argentina (30-37 3 ) especially in summer, the latter being attributed to an unrealistic simulation of the summer low-level jet east of the Andes.

The above-mentioned biases in CMIP-class climate simulations suggest that using precipitation projections for downstream applications and impact studies in the Andes should be done after applying bias correction techniques to the raw GCM outputs (e.g., Mourre et al., 2016; Heredia et al., 2018). In parallel, it is indispensable to improve the representation of the regional specificities of the Andes in any modeling effort, in order to better represent the interaction between main circulation and local complex orography, which is the cause of climate diversity in the Andes.

\section{Regional Climate Downscaling}

Since the hydroclimate diversity and complexity of the driving processes of the Andes can be hardly represented by the current generation of global models, dynamical and statistical downscaling techniques are widely used to assess climate change effects at regional scales. Several initiatives have been developed based on the implementation of Regional Climate Models (RCM) to produce high resolution climate simulations over the Andean region. Some of these initiatives are embedded within 

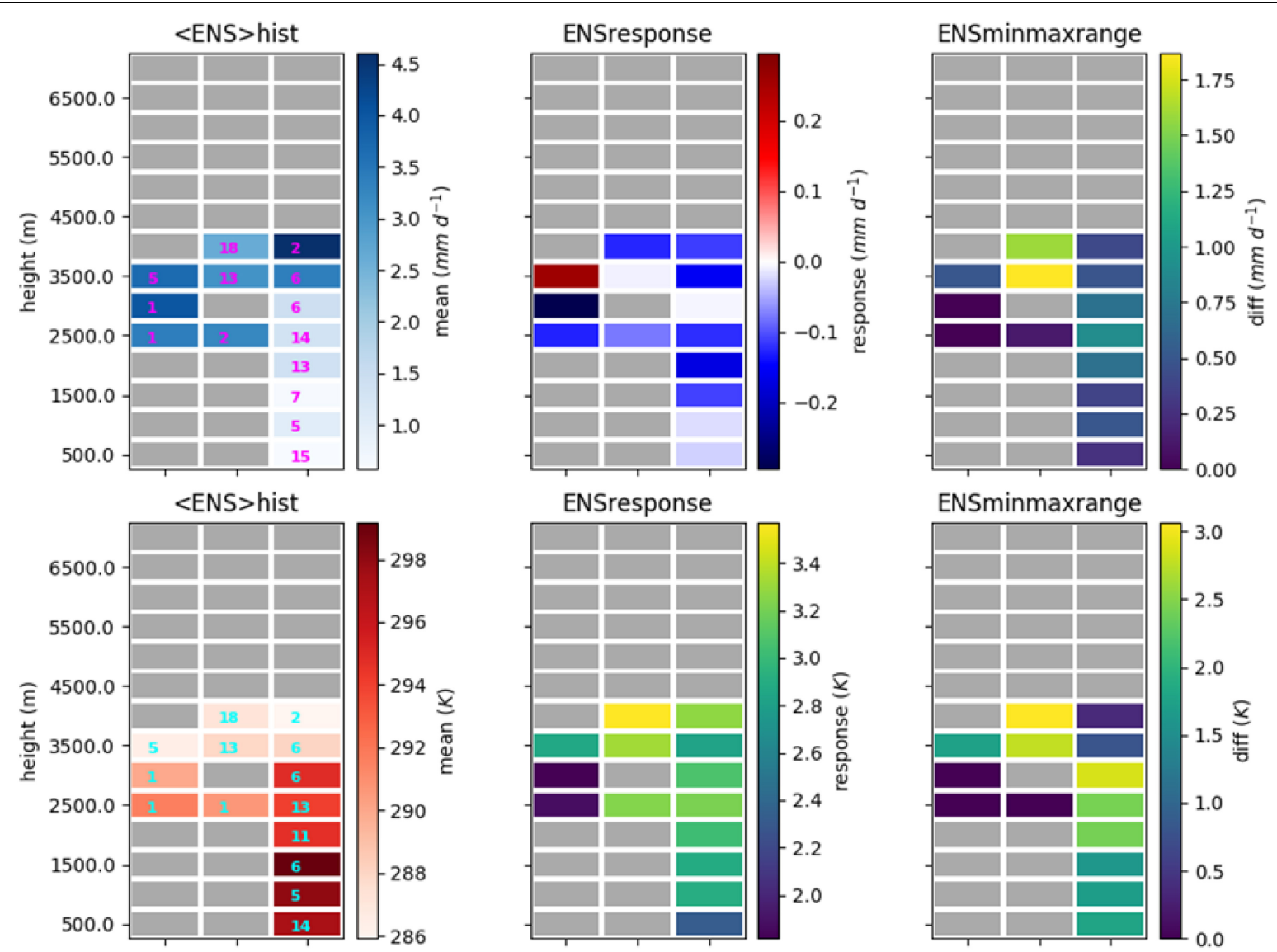

ENSresponse

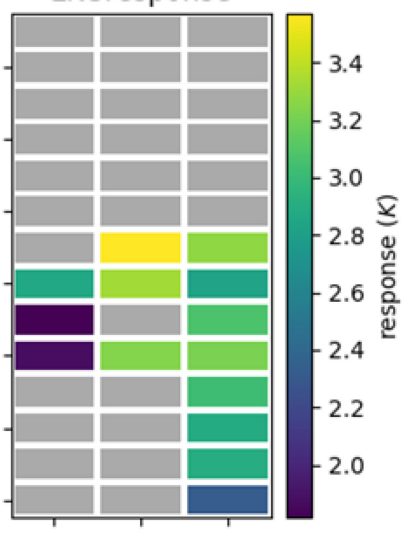

ENSresponse

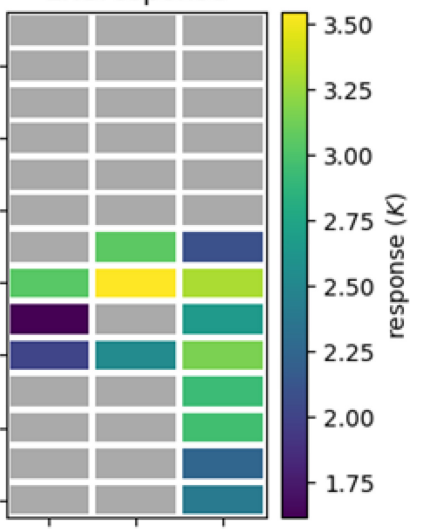

ENSminmaxrange
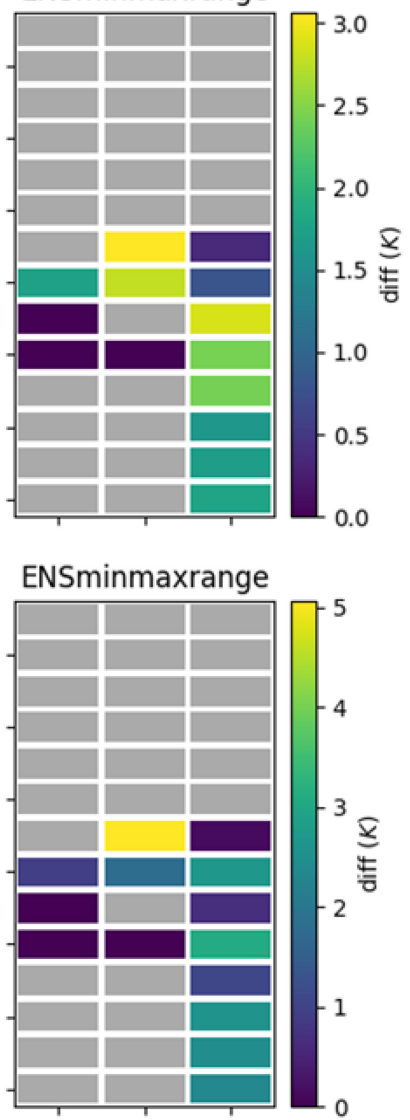

FIGURE 9 | Ensemble mean response to the projected climate change at Uyuni box, as a function of the height (discretized every 500 m) and mountain range face (uphill, peak and downhill represented, respectively, by vertical arrays in each box). Results are from 25 CMIP5 models, and for the scenario RCP8.5. First row is for the precipitation, second row is for the minimum 2-m temperature, and the third row is for the maximum 2-m temperature. Left column presents the ensemble mean value for the historical period (1960-1990), where pink/green numbers indicate how much models provide data for each slice, and slices without data are in gray. Middle column is for the change (2040-2070 minus 1960-1990) response. Right column is for the maximum range of the climate change signal.

a more general dynamical downscaling exercises developed under coordinated frameworks such as the Coordinated Regional Downscaling Experiment (CORDEX; Giorgi et al., 2009) and the CLARIS-LPB project (Solman, 2013; Boulanger et al., 2016), both covering the whole South American domain. This unprecedented set of RCM simulations have been performed with horizontal resolutions of roughly 22 and $50 \mathrm{~km}$. The assessment of the climate change signal for the end of the 21st century over the Andean region, as derived by this set of coordinated simulations, has been performed in several studies, such as Marengo et al. (2012a), Chou et al. (2014), Sánchez et al. (2015), Menéndez et al. (2016), Ambrizzi et al. (2018), and Zaninelli et al. (2019). 
Dynamical downscaling exercises over several regional domains covering different Andean subregions have also been performed at either 50 or $25 \mathrm{~km}$ horizontal resolution Marengo et al. (2009) for the whole South American continent; Urrutia and Vuille (2009) for tropical South America; Cabré et al. (2016) for southern South America, and Pabón (2012) for Colombia). All these studies based on dynamical downscaling tools agree on projecting a generalized warming over the Andean region by the end of the 21st century, ranging from $1^{\circ}$ to $5^{\circ}$, being the magnitude of the warming dependent on the region and the emission scenario used. Moreover, the projected warming is characterized by a complex spatial distribution, given the complexity of the topography in the region. Projected precipitation changes exhibit larger uncertainties (Buytaert et al., 2010), though common features can be highlighted, such as the drying over the western Andes south of $35^{\circ} \mathrm{S}$ during the $\mathrm{SH}$ winter season and the wetting over southern Chile during summer, in agreement with observed trends. For the northern Andes, most of the modeling exercises suggest a future increase in precipitation, though the sign in the projected precipitation change is highly dependent on the models used. The most interesting feature of all these modeling efforts is that the projected precipitation changes are characterized by a complex spatial distribution, with narrow areas of opposite projected changes over the Andes. Figure 10 displays the projected changes in seasonal mean temperature and precipitation from an ensemble of RCMs from Sánchez et al. (2015). Note that the ensemble (which includes projections from 10 RCMs) displays smooth changes in the temperature field, though the projected change in precipitation displays more complex features, particularly along the Andes. Inspection of changes from individual RCMs suggests more complex spatial patterns that are smooth out when building the ensemble. In addition to the aforementioned dynamical downscaling efforts, some authors have developed regional projections based on a variety of statistical downscaling tools (Minvielle and Garreaud, 2011; Boisier et al., 2015; Palomino-Lemus et al., 2015, 2017, 2018; Bozkurt et al., 2018, 2019). For northern Andes (north of $8^{\circ} \mathrm{S}$ ) Palomino-Lemus et al. $(2015,2017,2018)$ show a general increase of precipitation between 5\% and 20\% under the scenario RCP8.5. For the Altiplano region, Minvielle and Garreaud (2011) suggest a significant reduction $(10 \%-30 \%)$ in precipitation by the end of the 21th century under SRES A2 emission scenarios. Over the extratropical Andes, in the Central Chile region, Bozkurt et al. (2018) show large difference in drying between low and high emission scenarios (about $-3 \%$ in RCP2.6 and -30\% in RCP8.5), associated with warming of $1.2^{\circ} \mathrm{C}$ and $3.5^{\circ} \mathrm{C}$, respectively.

The reliability of the projected changes from RCMs may also be built after assessing the extent to which models are able to represent present climate conditions. Several studies have focused on assessing the reliability of regional climate models over the Andes and most of them found that RCMs usually present systematic biases, such as an underestimation of temperature at different altitudes (LópezFranca et al., 2016) and a overestimation of precipitation over the mountains, in particular over the eastern Andes slopes (Solman and Blazquez, 2019; see Figure 2a in Menéndez et al.,
2016). The origin of these biases lies, at least partly, in unresolved topographical forcing which remains too smoothed over the complex terrain of the Andes, limiting the simulation of regional processes such as the interactions between local circulation and orography, a key factor in climate modulation at meso-scale levels. However, even considering these systematic biases, recent studies have confirmed that CORDEX-type RCMs (e.g., with a spatial resolution of $20-50 \mathrm{~km}$ ) have the potential to add value in the representation of extreme precipitation and mean surface temperature over the Andes (Falco et al., 2018, 2019; Bozkurt et al., 2019).

Enhancing the spatial resolution in regional climate models is crucial in complex topography regions such as Andes, in particular for assessing the elevational dependence of warming, which has been already mentioned in section "Air Surface Temperature Trends in the Andes." Given that change in albedo is one of dominant drivers of EDW (Rangwala and Miller, 2012; Pepin et al., 2015), a realistic simulation of the seasonal transition between snow-covered and snow-free elevation requires fine spatial resolution allowing accurate representation of the topography (Palazzi et al., 2019). Furthermore, future elevation-dependent warming and associated wetting suggested by previous studies (e.g., Giorgi et al., 1997; Palazzi et al., 2017, 2019), may lead to locally enhanced convective activity and therefore affect locally precipitations. For instance, based on an ensemble of regional climate models simulations at approximately $12 \mathrm{~km}$ resolution, Giorgi et al. (1997) have demonstrated increasing precipitation in future climate projections over the European Alpine high peaks, whereas the forcing GCMs scenarios suggest reducing precipitation over the region. In order to investigate the role of local processes in the Andean precipitation response to global warming, related in particular to orography-atmosphere and land-atmosphere interactions, it is crucial to apply high-resolution modeling tools allowing resolving gamma-meso-scales $(2-20 \mathrm{~km})$. This issue becomes an important point for the regional research agenda. Currently, several projects are exploring the use of RCMs at gamma-mesoscale resolution for climate projections in different regions of the Andes (Bozkurt et al., 2019; Posada-Marín et al., 2019).

\section{Hydrological Projections and Impacts}

About surface hydrology projections, several sub-regional and small scale studies have been carried out. Exbrayat et al. (2014), using global climate projection produced for IPCC AR4 and AR5, found for the Ecuadorian Andes a likely increase in annual runoff by 2100 with a large variability between the different combinations of a climate model with a hydrological model, but they pointed out that differences between GCM projections introduced a gradually increasing relative uncertainty throughout the 21st century, and structural differences between applied hydrological models still contribute to a third of the total uncertainty in the late 21 st century runoff projections and differences between the two emission scenarios are marginal.

Ragettli et al. (2016), for a catchment in the subtropical Andes of Chile, found that runoff is likely to sharply decrease in the future and the runoff seasonality is sensitive to projected 

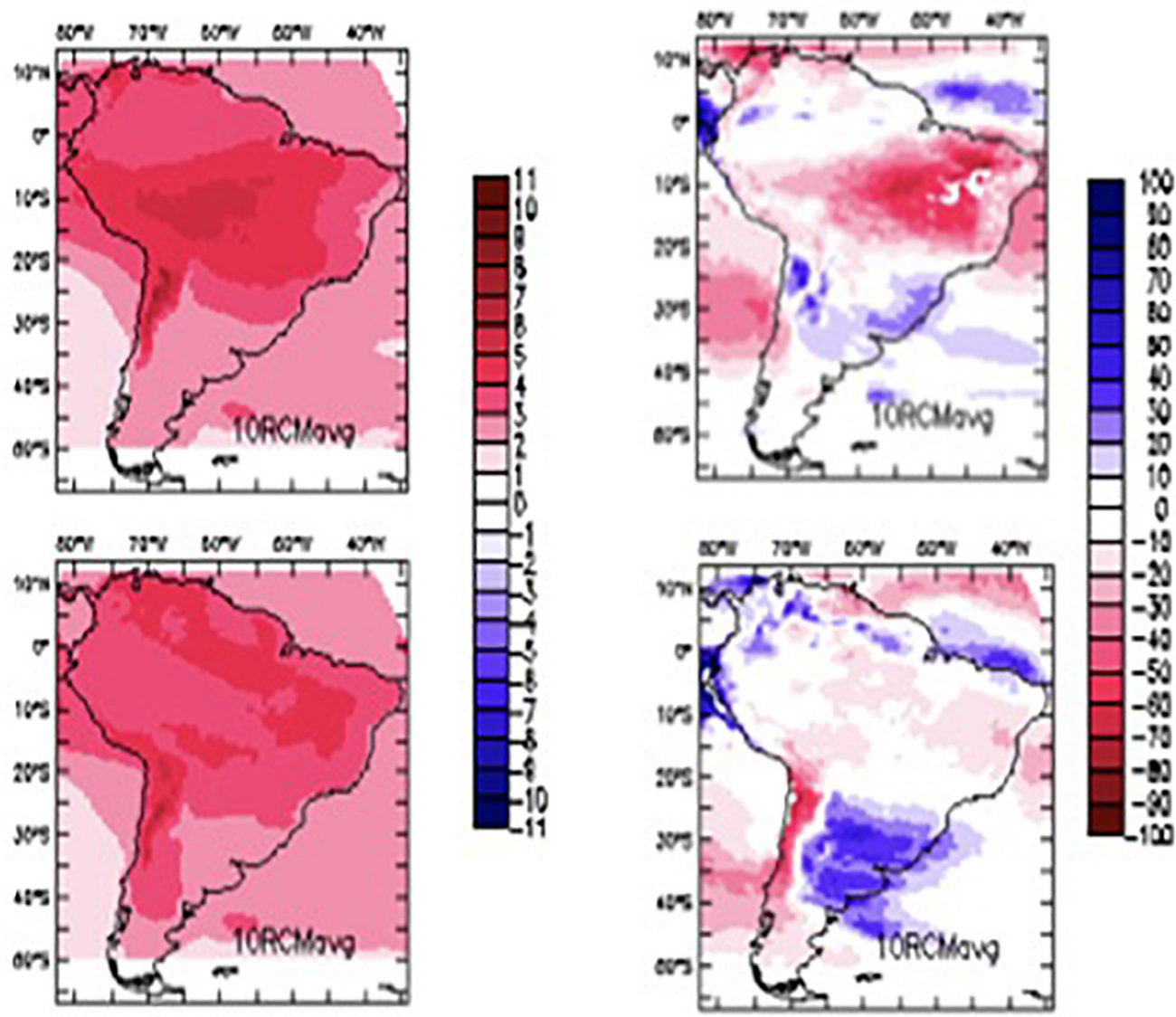

FIGURE 10 | Projections of seasonal mean temperature (left; in ${ }^{\circ} \mathrm{C}$ ) and seasonal mean precipitation (right; in\%) for the period $2071-2100$, according to an ensemble of RCMs for the SRES A1B scenario for JJA (top) and DJF (bottom). Adapted from Sánchez et al. (2015).

climatic changes. Their projections indicate that climate change adaptation in central Chile should focus on a reduction in water availability. Also, for Andean basins in Central Chile, Bozkurt et al. (2017) found that for 21st century droughts would be increased to up to 5 events/century and the probability of having more extended events; additionally, analyzing probability density function of annual maximum daily runoff they found an increase in the frequency of flood events. In the context of future climate change, most studies show a large range of uncertainty, but they project that an intensification of the hydrological cycle is likely to occur in the Amazon-Andes region (Guimberteau et al., 2013; Boisier et al., 2015; Marengo and Espinoza, 2016; Zulkafli et al., 2016). The aforementioned projected effects of climate change in the Andes will impact the ecosystems and human socioeconomic systems of the region (Young et al., 2011).

Large warming during the dry season in the Amazon river basin could shift the southern Amazon area toward a climate more appropriate to seasonal forests or savannah rather than tropical rain-forest (Oyama and Nobre, 2003; Salazar et al., 2007; Malhi et al., 2008; De Faria et al., 2017). Direct human intervention, including land use changes, the construction of new Andean dams in the Amazon basin, among others (e.g.,
Nobre et al., 2016; Forsberg et al., 2017), is also expected to increase in the future. This scenario represents a high risk of reduction of the atmospheric moisture generated by the Amazon rainforest evapotranspiration and its transport toward neighboring regions, such as the tropical Andes (Lejeune et al., 2015). Combined impacts of Amazon land use and climate changes could be even stronger in the Altiplano (Minvielle and Garreaud, 2011), a semiarid high plateau situated above 3600 m.a.s.l in the south tropical Andes $\left(14-23^{\circ} \mathrm{S}\right)$. In addition, the interaction between local-scale and regional-toglobal scale processes is a key topic of research to better understand tropical climate change, with surface conditions and water cycle playing a central role in such interactions (e.g., Builes-Jaramillo et al., 2017).

Schoolmeester et al. (2016) suggest that change in mean temperature and precipitation regime in the Andes, as well as glaciers melting, will have a marked effect on runoff and consequently on water availability for drinking, sanitation, agriculture, energy and industry. Mean temperature increase will alter biochemical composition of soil and vegetation, changing their capacity to regulate water flows. The increase and concentration of the water demand (due to population growth and urbanization) will have crucial effects on the water 
supply-demand balance, affecting water availability and causing regional conflicts that are necessary to anticipate. In this sense, improving our knowledge and information about these issues becomes extremely necessary.

\section{CONCLUDING REMARKS AND OPEN RESEARCH QUESTIONS}

The Andes have been subject of different hydroclimate changes throughout the past two millennia. Over the tropical Andes, paleoclimate evidence shows relatively warm conditions during the first centuries of the last millennium followed by colder temperature between the 15 th and 18 th centuries, suggesting the influence of MCA and LIA periods over tropical South America. Over the South American Altiplano (south tropical Andes) and central Chile (subtropical Andes), reconstructions indicate a persistent rainfall reduction since the mid-19th century to the beginning of the 21st century. Over the extratropical Andes, temperature reconstructions indicate that the 20th century has been the warmest period during the last millennium in the northern Patagonian, to the east of the Andes.

During the last decades, observational data suggest a general agreement on the occurrence of warmer temperatures over the Andes. However, there is not yet full agreement whether the rate of warming is amplified with elevation, which is particularly important in regions with complex topography, like the Andes. In this sense, the lack of a dense network of stations along the Andes does not allow addressing comprehensively this issue.

In contrast to temperature changes, trends in annual precipitation exhibit different signs across sectors in the Andes. For instance, annual precipitation trends in north tropical (north of $\left.8^{\circ} \mathrm{S}\right)$ and south tropical $\left(8^{\circ} \mathrm{S}-27^{\circ} \mathrm{S}\right)$ Andes do not show a homogeneous pattern. The Amazonian side of the north tropical Andes (northern and northwestern Amazon) has experienced wetter conditions since the mid-1990s, particularly during its wet season. In opposition, dry conditions have increased in austral winter and spring over the central and southern Amazon. Increases of rainfall during the 1965-1984 period and decreases since 1984 have been documented in Bolivia. In the Peruvian Andes, no significant rainfall trends are documented, although decreasing rainfall since 1970 has been reported by several studies in the central and southern Peruvian Amazon-Andes. Over the subtropical Andes, central Chile shows a robust signal of declining precipitation since 1970. Over the subtropical northwestern Argentinian Andes, precipitation trends are strongly dependent on elevation: the transition zone between low and intermediate elevations is characterized by the most significant positive annual rainfall trends since 1950, whereas at low elevations areas, generalized decreasing trends are observed.

Despite hydrological data shortcomings, several studies have provided further evidence of changes of surface runoff in the Andes. River runoff in the western Andes of Colombia, Ecuador, and Chile appears to increase significantly during the last 4-5 decades. Over Ecuador (tropical Andes), increasing trends in maximum flows and decreasing trends in minimum flows are found. Increasing frequency of droughts and floods in the Andean Amazon region has also been reported. In particular for this region, studies on different specific regions have found diverging trends in river discharge: decreasing discharge trends in the southern Amazon-Andes region (South of Peru and Bolivia) and increased trend in the north. In the Argentinian Andes, significant positive trends in river discharge during the last 5-6 decades are documented. Evidence of hydrological changes are also observed in the subtropical and extratropical Andes as changes of snow cover and glacier extension. The robust pattern of warmer temperatures and the overall recession of glaciers in the region suggest that such changes have impacted glacier mass balances in the subtropical and extratropical Andes, affecting river runoff. However, studies of monthly and annual mean discharge in the Andes show divergent trends (or no trends at all) and uncertainty is still large. In the central Andes of Chile and Argentina, the Norte Chico region in Chile, and the northwestern portion of Patagonia, river flows show marked negative trends. On the contrary, the river flows in northwestern Argentina and southern Bolivia, southern Patagonia, and Tierra del Fuego show positive trends with above-average values in the last decades.

LULC changes influence surface runoff in the Andes. Studies identify that cropland, pasture, and secondary vegetation over the north tropical Andes (north of $8^{\circ} \mathrm{S}$ ) showed systematic transitions, changing from a traditional land use to pasture. In particular, the main responsible forces of LULC change over this region are deforestation, agriculture, cattle ranching, and gold mining, although other socio-political dynamics are involved. High rates of deforestation are detected in the subtropical and extratropical Andes (Chile and Argentina), followed by the tropical Andes (Bolivia, Ecuador, Colombia and Peru). Such changes in LULC modify surface properties, affecting energy and water balances. Detailed studies addressed to understand how LULC changes influence hydroclimate in the Andes at local and regional scales are required.

Climate change projections over the Andes show general agreement on a future warming over the Andes, with the lowest values (less than $3^{\circ} \mathrm{C}$ ) over extratropical latitudes and the highest values (up to $5^{\circ} \mathrm{C}$ ) over the central region. By contrast, projections of precipitation in the Andes exhibit higher spread among models and uncertainties. The only agreement among models in the Andean region is the drying trend over central Chile, located in the subtropical Andes, which has been already evidenced as an emerging anthropogenic signal from a background observed variability.

The difficulty of GCMs to adequately simulate and project precipitation changes in the Andes is highly associated with their coarse spatial resolution. Therefore, downscaling simulations are required in order to provide more detailed information at local scale. This is an ongoing research area. For instance, CORDEX and CLARIS-LPB projects have allowed the development of dynamical downscaling using RCMs for climate change projections in the Andes, whereas different studies have used dynamical and statistical tools suggesting a general increase of precipitation over the northern Andes (north of $8^{\circ} \mathrm{S}$ ) and a significant reduction $(10 \%-30 \%)$ in precipitation by the end of the 21 th century over the western 
subtropical Andes. However, RCMs at CORDEX-type resolution $(20-50 \mathrm{~km})$ exhibit biases such as the underestimation of temperature at different altitudes of mountains and the overestimation of precipitation over mountain regions, in particular over the eastern Andes slopes, in association with unresolved topographical forcing which remains too smoothed over the complex terrain of the Andes. Higherresolution models allowing resolving gamma-meso-scales $(2-20 \mathrm{~km})$ are needed for a more accurate representation of the topography of the Andes and by consequence for a more realistic simulation of orography-atmosphere and land-atmosphere interactions.

This review highlights the necessity of strengthening different research areas in order to provide a more comprehensive understanding of past, present and future hydroclimate changes over the Andes. In this sense, it allowed to identify open questions tend to indicate research areas to be pursued by the scientific community. Amongst them, we identify the following topics as the more relevant to be addressed:

- The immense variety of meso-climates of the Andes, as a consequence of the interaction of large-scale circulation with complex topography and regional circulations systems, requires a more detailed assessment in hydroclimate studies. Generalized views of large subregions in terms of climate trends and future scenarios is not sufficient to represent the real processes of this environmental diversity. Therefore, a more detailed spatial view is needed in terms of observed trends and projected climate change scenarios in the Andes. This request to put on any regional research agenda the challenge of producing more detailed high-quality data, and the development of very high spatial resolution modeling and dynamically robust methodologies of analysis.

- There are different regional-to-local scale processes which require a further understanding of hydroclimate changes in the Andes. The most relevant are the altitude and latitude dependence on the warming signal and the LULC changes. Efforts are necessary in order to produce more detailed knowledge on these specific topics for a variety of sub-regions, stressing the importance of the impacts of LULC change in the hydrological cycle at local and regional scale. To achieve this objective, several orientedcase studies based on observational and high-resolution numerical modeling approaches have to be promoted.

- Some authors have described diverse mechanisms and feedbacks that could contribute to EDW and at what heights each one plays a role (Rangwala and Miller, 2012; Pepin et al., 2015; Palazzi et al., 2017). It is believed that complex interactions among snow and other land-cover albedo, water vapor changes and latent heat release, surface heat loss, surface water vapor and radiative flux changes, aerosols, among others, could explain the EDW. However, they could play different roles at individual heights and
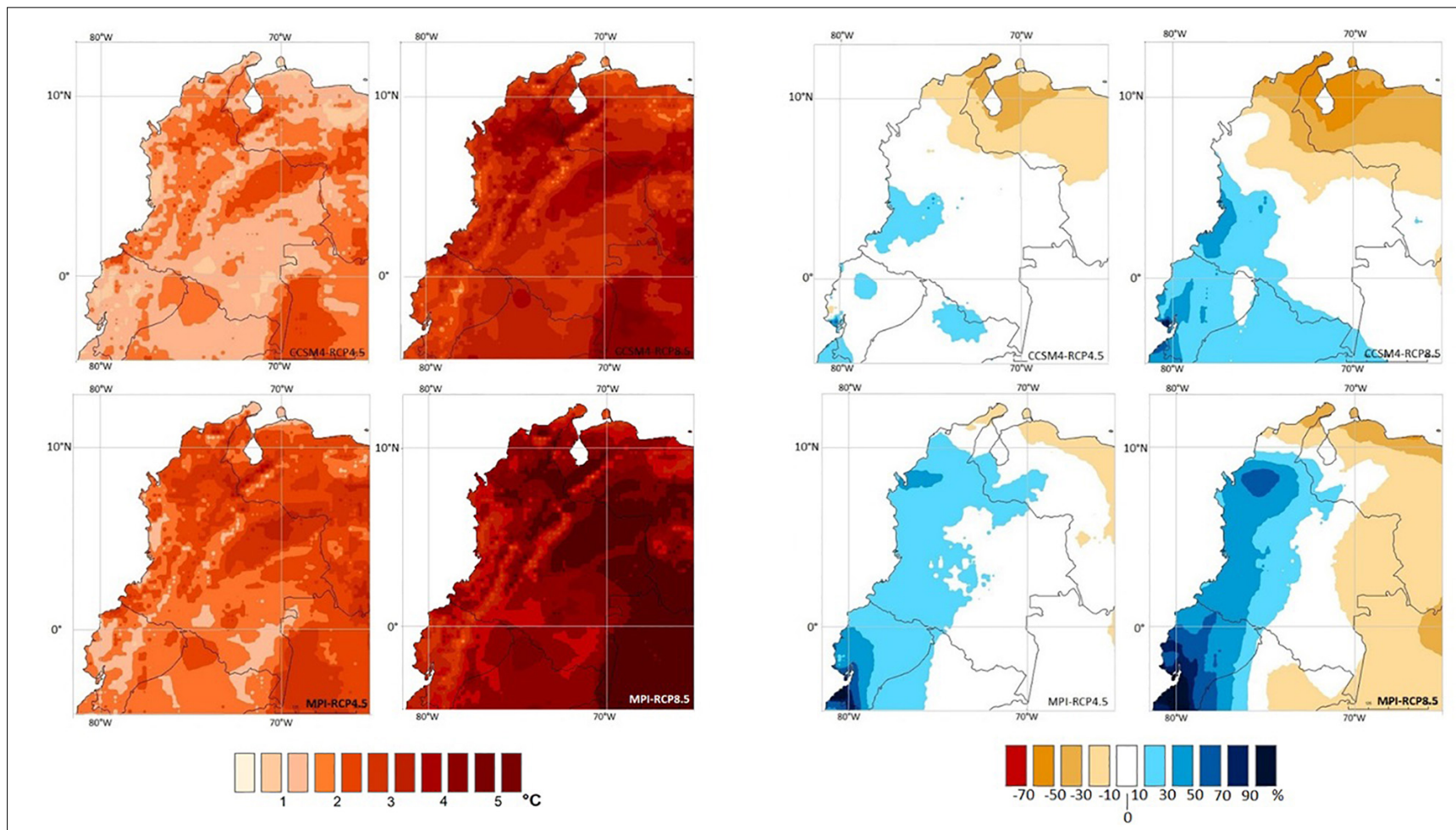

FIGURE 11 | Projected changes in annual temperature (left; in ${ }^{\circ} \mathrm{C}$ ) and annual precipitation (right; in\% related to annual average $1976-2005$ period) over the north tropical Andes as obtained with dynamical downscaling of CCSM4 (top) and MPI (bottom) under RCP4.5 and RCP8.5 scenarios. Weather Research Forecast (WRF) model was used to downscale to spatial resolution $10 \times 10 \mathrm{~km}$. After Armenta-Porras and Pabón-Caicedo (2018). 
locations, clarifying the contrasting trends documented by different authors (e.g., Vuille and Bradley, 2000; Ohmura, 2012; Wang et al., 2014). On the other hand, the PDO fingerprint is visible on the western Andes at low elevations locations (Vuille et al., 2015): while coastal regions have been recently affected by a cooling along the Andes, inland and higher elevations regions continue to warm. Therefore, the first question to answer is about the capability of simulations with prescribed SSTs (AMIP) to reproduce these mechanisms. Future warming or cooling in the Andes, as well as its EDW, will depend on regional-to-local feedbacks but also on the balance between the global warming forcing and the state of the PDO.

- Regarding climate change projections for the Andes, besides detailed spatial information that represents the diversity of climate conditions, it is necessary to reduce uncertainties in currently produced scenarios. In this sense, efforts are needed for improving the models used to simulate hydroclimate processes over this region, including the impacts of LULC changes in regional atmospheric circulation (e.g., Saavedra et al., 2018). Improvement and innovations are also needed to develop methodologies for downscaling of global/regional models, as well as new analysis methods over regions with complex topography. For instance, Figure 11 shows an example of ongoing efforts to produce very high resolution $(10 \mathrm{~km})$ projections over the north tropical Andes (Armenta-Porras and PabónCaicedo, 2018). Also, it is mandatory to take advantage of the information provided by the incoming CMIP6 exercise for a better representation of hydroclimate processes in the Andes. In particular, high resolution downscaling of climate change projections at convective permitting resolutions (higher than $5 \mathrm{~km}$ ) in a coordinated effort are urgently required.

- There is an urgent need to better understand the impact on the projected climate changes over the Andes, since it holds most of the ecological, social and economic systems in South America. This is primordial to properly design

\section{REFERENCES}

Abram, N. J., McGregor, H. V., Tierney, J. E., Evans, M. N., McKay, N. P., Kaufman, D. S., et al. (2016). Early onset of industrial-era warming across the oceans and continents. Nature 536, 411-418. doi: 10.1038/nature19082

Agudelo, J., Arias, P. A., Vieira, S. C., and Martínez, J. A. (2019). Influence of longer dry seasons in the Southern Amazon on patterns of water vapor transport over northern South America and the Caribbean. Clim. Dyn. 52, 2647-2665. doi: 10.1007/s00382-018-4285-1

Aguilar-Lome, J., Espinoza-Villar, R., Espinoza, J.-C., Rojas-Acuña, J., Willems, B. L., and Leyva-Molina, W.-M. (2019). Elevation-dependent warming of land surface temperatures in the Andes assessed using MODIS LST time series (2000-2017). Int. J. Appl. Earth Observ. Geoinf. 77, 119-128. doi: 10.1016/j.jag. 2018.12.013

Ahmed, M., Anchukaitis, K. J., Asrat, A., Borgaonkar, H. P., Braida, M., Buckle, B. M., et al. (2013). Continental-scale temperature variability during the past two millennia. Nat. Geosci. 6, 339-346. doi: 10.1038/ngeo1797

Aide, T. M., Grau, H. R., Graesser, J., Andrade-Nuñez, M. J., Aráoz, E., Barros, A. P., et al. (2019). Woody vegetation dynamics in the tropical and subtropical strategies of adaptation and mitigation in order to prevent potential socio-economical conflicts in the entire continent (e.g., Salazar A. et al., 2018).

\section{AUTHOR CONTRIBUTIONS}

All authors contributed to the conception, discussion, and refinement of this manuscript.

\section{FUNDING}

This review manuscript has been achieved as part of the ANDEX program (www.gewex.org/project/andex/), which is a prospective Regional Hydroclimate Project (RHP) of the GEWEX Hydroclimatology Panel (GHP). JP-C was partially supported by Centro Internacional para la Investigación del Fenómeno de El Niño (CIIFEN). PA was supported by Universidad de Antioquia through the Grant CODI PRG2017-16264. AC also thanks the ANPCyT (Argentina) that partially supported this work through the PICT-2015-3097. JE was supported by the French AMANECER-MOPGA project funded by ANR and IRD (ref. ANR-18-MPGA-0008). MM and RV were funded by Consejo Nacional de Investigaciones Científicas y Técnicas (CONICET) - Argentina. RV was partially supported by BNP Paribas through the project THEMES. Finally, this article has the support of UNESCO's Intergovernmental Hydrological Programme through the Working Group Hydrogeomorphology of the Andes-Amazon Basin in which PA, JE, and WL-C participated. The views presented in this manuscript are those of the authors and do not compromise the Working Group or UNESCO in any way.

\section{ACKNOWLEDGMENTS}

The authors acknowledge Geusep Ortega for his help with Figure 7 and the two reviewers for their insightful comments on this manuscript.

Andes from 2001 to 2014: satellite image interpretation and expert validation. Glob. Change Biol. 25, 2112-2126. doi: 10.1111/gcb.14618

Altinger de Schwarzkopf, M. L., and Rosso, L. C. (1982). "Severe storms and tornadoes in Argentina," in Proceedings of the 12th Conf. on Severe Local Storms (San Antonio, TX: Amer. Meteor. Soc), 59-62.

Ambrizzi, T., Reboita, M. S., da Rocha, R. P., and Llopart, M. (2018). The state-of-the-art and fundamental aspects of regional climate modeling in South America. Ann. N. Y. Acad. Sci. 1436, 98-120. doi: 10.1111/nyas.1 3932

Aravena, J. C., Lara, A., Wolodarsky-Franke, A., Villalba, R., and Cuq, E. (2002). Tree-ring growth patterns and temperature reconstruction from Nothofagus pumilio (Fagaceae) forests at the upper tree line of southern Chilean Patagonia. Rev. Chil. Hist. Nat. 75, 361-376.

Arias, P. A., Fo, R., Vera, C., and Rojas, M. (2015). A correlated shortening of the North and South American monsoon seasons in the past few decades. Clim. Dyn. 45, 3183-3203. doi: 10.1007/s00382-015-2533-1

Armenta-Porras, G. E., and Pabón-Caicedo, J. D., (2018). "Producing high spatial resolution climate scenarios for tropical america and colombia using WRF model," in CORDEX Central America and South America Training Workshop 
on Downscaling Techniques, La Paz. Available at: http://www.cima.fcen.uba.ar/ cordex-2018/poster.php.

Armenteras, D., Rodríguez, N., and Retana, J. (2017). Deforestation dynamics and drivers in different forest types of Latin America: three decades of studies (19802010). Global Environ. Change 46, 139-147. doi: 10.1016/j.gloenvcha.2017. 09.002

Armenteras, D., Rodríguez, N., Retana, J., and Morales, M. (2011). Understanding deforestation in montane and lowland forests of the colombian andes. Reg. Environ. Change 11, 693-705. doi: 10.1007/s10113-010-0200-y

Armijos, E., Crave, A., Vauchel, P., Fraizy, P., Santini, W., Moquet, J.-S., et al. (2013). Suspended sediment dynamics in the Amazon River of Peru. J. S. Am. Earth Sci. 44, 75-84. doi: 10.1016/j.jsames.2012.09.002

Balthazar, V., Vanacker, V., Molina, A., and Lambin, E. F. (2015). Impacts of forest cover change on ecosystem services in high Andean mountains. Ecol. Indic. 48, 63-75. doi: 10.1016/j.ecolind.2014.07.043

Barichivich, J., Gloor, E., Peylin, P., Brienen, R. J. W., Schöngart, J., Espinoza, J. C., et al. (2018). Recent intensification of Amazon flooding extremes driven by strengthened Walker circulation. Sci. Adv. 4:eaat8785. doi: 10.1126/sciadv. aat 8785

Barkhordarian, A., von Storch, H., Zorita, E., Loikith, P. C., and Mechoso, C. R. (2017). Observed warming over northern South America has an anthropogenic origin. Clim. Dyn. 51, 1901-1914. doi: 10.1007/s00382-017-3988-z

Barry, R., and Seimon, A. (2000). Research for mountain area development: climatic fluctuations in the mountains of the Americas and their significance. Ambio 29, 364-370. doi: 10.1579/0044-7447-29.7.364

Bianchi, E., Villalba, R., Viale, M., Couvreux, F., and Marticorena, R. (2016). New precipitation and temperature grids for northern patagonia: advances in relation to global climate grids. J. Meteorol. Res. 30, 38-52. doi: 10.1007/s13351015-5058-y

Bird, B. W., Abbott, M. B., Vuille, M., Rodbell, D. T., Rosenmeier, M. F., and Stansell, N. D. (2011). A 2300-year-long annually resolved record of the South American summer monsoon from the Peruvian Andes. Proc. Natl. Acad. Sci. U.S.A. 108, 8583-8588. doi: 10.1073/pnas.1003719108

Blázquez, J., and Nuñez, M. N. (2013). Analysis of uncertainties in future climate projections for South America: comparison of WCRP-CMIP3 and WCRP-CMIP5 models. Clim. Dyn. 41, 1039-1056. doi: 10.1007/s00382-0121489-7

Boers, N., Marwan, N., Barbosa, H. M. J., and Kurths, J. (2017). A deforestationinduced tipping point for the South American monsoon system. Sci. Rep. 7:41489. doi: $10.1038 /$ srep41489

Boisier, J. P., Alvarez-Garreton, C., Cordero, R., Damian, A., Gallardo, L., Garreaud, R., et al. (2018). Anthropogenic drying in central-southern Chile evidenced by long term observations and climate model simulations. Elem. Sci. Anth. 6:74. doi: 10.1525/elementa.328

Boisier, J. P., Ciais, P., Ducharne, A., and Guimberteau, M. (2015). Projected strengthening of Amazonian dry season by constrained climate model simulations. Nat. Clim. Change 5, 656-660. doi: 10.1038/nclimate2658

Boisier, J. P., Rondanelli, R., Garreaud, R. D., and Muñoz, F. (2016). Anthropogenic and natural contributions to the southeast Pacific precipitation decline and recent megadrought in central Chile. Geophys. Res. Lett. 43, 413-421. doi: 10.1002/2015gl067265

Bonan, G. B., Defries, R. S., Coe, M. T., and Ojima, D. S. (2012). "Land use and climate," in GUTMAN, eds G. Gutman, A. C. Janetos, C. O. Justice, E. F. Moran, J. F. Mustard, R. R. Rindfuss, et al. (Dordrecht: Springer), 467,307-320.

Bonilla-Ovallos, C. A., and Mesa, O. J. (2017). Validación de la precipitación estimada por modelos climáticos acoplados del proyecto de intercomparación CMIP5 en Colombia. Rev. Acad. Colomb. Cienc. Ex. Fis. Nat. 41, 107-118. doi: $10.18257 /$ raccefyn.27

Bonnesoeur, V., Locatelli, B., Guariguata, M. R., Ochoa-Tocachi, B. F., Vanacker, V., Mao, Z., et al. (2019). Impacts of forests and forestation on hydrological services in the Andes: a systematic review. For. Ecol. Manage. 433, 569-584. doi: 10.1016/j.foreco.2018.11.033

Boulanger, J. P., Carril, A. F., and Sánchez, E. (2016). CLARIS-La Plata Basin: the regional climate variability and the analysis of an ensemble of regional hydroclimate scenarios and their uncertainties. Clim. Res. 68, 93-94. doi: 10. $3354 / \mathrm{cr} 01392$

Bozkurt, D., Rojas, M., Boisier, J. B., Rondanelli, R., Garreaud, R., et al. (2019). Dynamical downscaling over the complex terrain of southwest
South America: present climate conditions and added value analysis. Clim. Dyn. 53, 6745-6767. doi: 10.1007/s00382-019-04959-y

Bozkurt, D., Rojas, M., and Boisier, J. P. (2018). Projected hydroclimate changes over Andean basins in central Chile from downscaled CMIP5 models under the low and high emission scenarios. Clim. Change 150:131. doi: 10.1007/s10584018-2246-7

Bozkurt, D., Rojas, M., Boisier, J. P., and Valdivieso, J. (2017). Climate change impacts on hydroclimatic regimes and extremes over Andean basins in central Chile. Hydrol Earth Syst. Sci. Discuss. 2017, 1-29. doi: 10.5194/hess-2016-690

Bradley, R. S. (2013). Paleoclimatology: Reconstructing Climates of the Quaternary, 3rd Edn. Amsterdam: Elsevier.

Brönnimann, S., Franke, J., Nussbaumer, S. U., Zumbühl, H. J., Steiner, D., Trachsel, M., et al. (2019). Last phase of the Little Ice Age forced by volcanic eruptions. Nat. Geosci. 12, 650-656. doi: 10.1038/s41561-019-0402-y

Builes-Jaramillo, A., Marwan, N., Poveda, G., and Kurths, J. (2017). Nonlinear interactions between the Amazon River basin and the Tropical North Atlantic at interannual timescales. Clim. Dyn. 50, 2951-2969. doi: 10.1007/s00382-0173785-8

Burger, F., Brock, B., and Montecinos, A. (2018). Seasonal and elevational contrasts in temperature trends in Central Chile between 1979 and 2015. Global Planet. Change 162, 136-147. doi: 10.1016/j.gloplacha.2018.01.005

Buytaert, W., and Beven, K. (2009). Regionalization as a learning process. Water Resour. Res. 45:W11419. doi: 10.1029/2008WR007359

Buytaert, W., Vuille, M., Dewulf, A., Urrutia, R., Karmalkar, A., and Célleri, R. (2010). Uncertainties in climate change projections and regional downscaling in the tropical Andes: implications for water resources management. Hydrol. Earth Syst. Sci. 14, 1247-1258. doi: 10.5194/hess-14-1247-2010

Cabré, M. F., Solman, S., and Nuñez, M. (2016). Regional climate change scenarios over southern South America for future climate (2080-2099) using the MM5 Model. Mean, interannual variability and uncertainties. Atmósfera 15, 35-60. doi: 10.20937/ATM.2016.29.01.04

Carmona, A. M., and Poveda, G. (2014). Detection of long-term trends in monthly hydro-climatic series of Colombia through Empirical Mode Decomposition. Clim. Change 123, 301-313. doi: 10.1007/s10584-013-1046-3

Carvajal-Vanegas, A. F., and Pabón-Caicedo, J. D. (2014). Temperatura de la superficie terrestre en diferentes tipos de cobertura de la región andina colombiana. Soc. Natureza 26, 95-112. doi: 10.1590/1982-45132014 0107

Castino, F., Bookhagen, B., and Strecker, M. R. (2016). Rainfall variability and trends of the past six decades (1950-2014) in the subtropical NW Argentine Andes. Clim. Dyn. 48, 1049-1067. doi: 10.1007/s00382-016$3127-2$

Celeri, R., and Feyen, J. (2009). The hydrology of tropical andean ecosystems: importance, knowledge status, and perspectives. Mount. Res. Dev. 29, 350-355. doi: $10.1659 / \mathrm{mrd} .00007$

Chavez, S. P., and Takahashi, K. (2017). Orographic rainfall hot spots in the AndesAmazon transition according to the TRMM precipitation radar and in situ data. J. Geophys. Res. 112, 5870-5882. doi: 10.1002/2016JD026282

Chou, S. C., Lyra, A., Mourão, C., Dereczynski, C., Pilotto, I., Gomes, J., et al. (2014). Assessment of climate change over South America under RCP 4.5 and 8.5 downscaling scenarios. Am. J. Clim. Change 3, 512-525. doi: 10.4236/ajcc. 2014.35043

Christie, D. A., Lara, A., Barichivich, J., Villalba, R., Morales, M. S., and Cuq, E. (2009). El Niño-Southern Oscillation signal in the world's highest-elevation tree-ring chronologies from the Altiplano, Central Andes. Palaeogeogr. Palaeoclimatol. Palaeoecol. 281, 309-319. doi: 10.1016/j.palaeo.2007.11.013

Dätwyler, C., Neukom, R., Abram, N. J., Gallant, A. J. E., Grosjean, M., JacquesCoper, M., et al. (2018). Teleconnection stationarity, variability and trends of the Southern Annular Mode (SAM) during the last millennium. Clim. Dyn. 51, 2321-2339. doi: 10.1007/s00382-017-4015-0

De Faria, B. L., Brando, P. M., Macedo, M. N., Panday, P. K., Soares-Filho, B. S., and Coe, M. T. (2017). Current and future patterns of fire-induced forest degradation in Amazonia. Environ. Res. Lett. 12:095005. doi: 10.1088/17489326/aa69ce

de los Skansi, M., Brunet, M., Sigró, J., Aguilar, E., Arevalo Groening, J. A., Bentancur, O. J., et al. (2013). Warming and wetting signals emerging from analysis of changes in climate extreme indices over South America. Glob. Planet. Change 100, 295-307. doi: 10.1016/j.gloplacha.2012.11.004 
Diaz, I. G., Nahuelhual, L., Echeverría, C., and Marín, S. (2011). Drivers of land abandonment in Southern Chile and implications for landscape planning. Landsc. Urban Plann. 99, 207-217. doi: 10.1016/j.landurbplan.2010.11.005

Espinoza, J. C., Chavez, S., Ronchail, J., Junquas, C., Takahashi, K., et al. (2015). Rainfall hotspots over the southern tropical andes: spatial distribution, rainfall intensity, and relations with large-scale atmospheric circulation. Water Resour. Res. 51, 3459-3475. doi: 10.1002/2014WR016273

Espinoza, J. C., Guyot, J. L., Ronchail, J., Cochonneau, G., Filizola, N., Fraizy, P., et al. (2009). Contrasting regional discharge evolutions in the Amazon basin (1974-2004). J. Hydrol. 375, 297-311. doi: 10.1016/j.jhydrol.2009.03.004

Espinoza, J. C., Ronchail, J., Frappart, F., Lavado, W., Santini, W., and Guyot, J. L. (2013). The major floods in the amazonas river and tributaries (Western Amazon Basin) during the 1970-2012 Period: a Focus on the 2012 Flood*. J. Hydrometeorol. 14, 1000-1008. doi: 10.1175/jhm-d-12-0100.1

Espinoza, J. C., Ronchail, J., Guyot, J. L., Junquas, C., Vauchel, P., Lavado, W. S., et al. (2011). Climate variability and extremes drought in the upper Solimões River (Western Amazon Basin): understanding the exceptional 2010 drought. Geophys. Res. Lett. 38:L13406. doi: 10.1029/2011GL047862

Espinoza, J. C., Ronchail, J., Marengo, J. A., and Segura, H. (2019a). Contrasting North-South changes in Amazon wet-day and dry-day frequency and related atmospheric features (1981-2017). Clim. Dyn. 52, 5416-5430. doi: 10.1007/ s00382-018-4462-2

Espinoza, J. C., Sörensson, A., Ronchail, J., Molina-Carpio, J., Segura, H., Gutierrez-Cori, O., et al. (2019b). Regional hydro-climatic changes in the Southern Amazon Basin (Upper Madeira Basin) during the 1982-2017 period. J. Hydrol. Reg. Stud. 26:100637. doi: 10.1016/j.ejrh.2019.100637

Etter, A., McAlpine, C., and Possingham, H. (2008). Historical patterns and drivers of landscape change in colombia since 1500: a regionalized spatial approach. Ann. Assoc. Am. Geograph. 98, 2-23. doi: 10.1080/00045600701733911

Exbrayat, J.-F., Buytaert, W., Timbe, E., Windhorst, D., and Breuer, L. (2014). Addressing sources of uncertainty in runoff projections for a data scarce catchment in the Ecuadorian Andes. Clim. Change 125, 221-235. doi: 10.1007/ s10584-014-1160-x

Falco, M., Carril, A. F., Li, L. Z. X., Cabrelli, C., and Menéndez, C. G. (2019). The potential added value of regional climate models in South America using a multiresolution approach. Clim. Dyn. 54, 1553-1569. doi: 10.1007/s00382-01905073-9

Falco, M., Carril, A. F., Menéndez, C. G., Zaninelli, P. G., Laurent, Z., and Li, X. (2018). Assessment of CORDEX simulations over South America: added value on seasonal climatology and resolution considerations. Clim. Dyn. 52, 4771-4786. doi: 10.1007/s00382-018-4412-z

Falvey, M., and Garreaud, R. (2007). Wintertime precipitation episodes in Central Chile: associated meteorological conditions and orographic influences. J. Hydrometeor. 8, 171-193. doi: 10.1175/jhm562.1

Falvey, M., and Garreaud, R. D. (2009). Regional cooling in a warming world: recent temperature trends in the southeast Pacific and along the west coast of subtropical South America (1979-2006). J. Geophys. Res. 114, 1-16. doi: 10.1029/2008JD010519

Farley, K. A., Jobba'gy, E. G., and Jackson, R. B. (2005). Effects of afforestation on water yield: a global synthesis with implications for policy. Global Change Biol. 11, 1565-1576. doi: 10.1111/j.1365-2486.2005.01011.x

Fita, L., Carril, A. F., Flombaum, P., Menéndez, C., Ruscica, R., Sörensson, A., Zaninelli, P. (2019). "Results of a new methodology to analyze the climate change uncertainty on a high step mountain range. Application at the Andes," in International Conference on Regional Climate-CORDEX 2019, 14th-18th October, Beijing.

Flantua, S. G. A., (2017). Climate Change and Topography as Drivers of Latin American Biome Dynamics. Doctoral thesis, University of Amsterdam, Amsterdam.

Forsberg, B. R., Melack, J. M., Dunne, T., Barthem, R. B., Goulding, M., Paiva, R. C. D., et al. (2017). The potential impact of new Andean dams on Amazon fluvial ecosystems. PLoS ONE 12:e0182254. doi: 10.1371/journal.pone.0182254

Fu, R., Yin, L., Li, W., Arias, P. A., Dickinson, R. E., Huang, L., et al. (2013). Increased dry-season length over southern Amazonia in recent decades and its implication for future climate projection. Proc. Natl. Acad. Sci. U.S.A. 110, 18110-18115. doi: 10.1073/pnas.1302584110

Garreaud, R., Alvarez-Garreton, C., Barichivich, J., Boisier, J. P., Christie, D. A., Galleguillos, M., et al. (2017). The 2010-2015 mega drought in Central
Chile: impacts on regional hydroclimate and vegetation. Hydrol. Earth Syst. Sci. 21, 6307-6327. doi: 10.5194/hess-21-6307-2017

Garreaud, R. D., Vuilles, M., Compagnucci, R., and Marengo, J. A. (2009). Presentday South American climate. Palaeogeogr. Palaeoclimatol. Palaeoecol. 281, 180-195. doi: 10.1016/j.palaeo.2007.10.032

Gimeno, L., Dominguez, F., Nieto, R., Trigo, R., Drumond, A., Reason, C. J. C., et al. (2016). Major mechanisms of atmospheric moisture transport and their role in extreme precipitation events. Annu. Rev. Environ. Resour. 41, 117-141. doi: 10.1146/annurev-environ-110615-085558

Giorgi, F., Hurrell, J. W., Marinucci, M. R., and Beniston, M. (1997). Elevation dependency of the surface climate change signal: a model study. J. Clim. 10, 288-296. doi: 10.1175/1520-0442(1997)010<0288:edotsc > 2.0.co;2

Giorgi, F., Jones, C., and Asrar, G. (2009). Addressing climate information needs at the regional level: the CORDEX framework. WMO Bull. 58, 175-183.

Gloor, M., Brienen, R. J. W., Galbraith, D., Feldpausch, T. R., Schöngart, J., Guyot, J.-L., et al. (2013). Intensification of the Amazon hydrological cycle over the last two decades. Geophys. Res. Lett. 40, 1729-1733. doi: 10.1002/grl.50377

González-Reyes, Á, McPhee, J., Christie, D. A., Le Quesne, C., Szejner, P., Masiokas, M. H., et al. (2017). Spatiotemporal Variations in ydroclimate across the Mediterranean Andes $\left(30-37^{\circ} ? \mathrm{~S}\right)$ since the Early Twentieth Century. J. Hydrometeorol. 18, 1929-1942. doi: 10.1175/JHM-D-16-0004.1

Guimberteau, M., Ronchail, J., Espinoza, J. C., Lengaigne, M., Sultan, B., Polcher, J., et al. (2013). Future changes in precipitation and impacts on extreme streamflow over Amazonian sub-basins. Environ. Res. Lett. 8:014035. doi: 10. 1088/1748-9326/8/1/014035

Haarsma, R. J., Roberts, M. J., Vidale, P. L., Senior, C. A., Bellucci, A., Bao, Q., et al. (2016). High resolution model intercomparison project (HighResMIP v1.0) for CMIP6. Geosci. Model Dev. 9, 4185-4208. doi: 10.5194/gmd-9-4185-2016

Hartman, L. H., Kurbatov, A. V., Winski, D. A., Cruz-Uribe, A. M., Davies, S. M., Dunbar, N. W., et al. (2019). Volcanic glass properties from 1459 C.E. volcanic event in South Pole ice core dismiss Kuwae caldera as a potential source. Sci. Rep. 9, 1-7. doi: 10.1038/s41598-019-50939-x

Heidinger, H., Calrvalho, L., Jones, C., Posadas, A., and Quiroz, R. (2018). A new assessment in total and extreme rainfall trends over central and southern Peruvian Andes during 1965-2010. Int. J. Climatol. 38, e998-e1015. doi: 10. $1002 /$ joc. 5427

Heredia, M. B., Junquas, C., Prieur, C., and Condom, T. (2018). New Statistical methods for precipitation bias correction applied to WRF model simulations in the antisana region (Ecuador). J. Hydrometeorol. 19, 2021-2040. doi: 10.1175/ JHM-D-18-0032.1

Hoffman, C., García-Márquez, J. R., and Krueger, T. (2018). A local perspective on drivers and measures to slow deforestation in the Andean-Amazonian foothills of Colombia. Land Use Policy 77, 379-391. doi: 10.1016/j.landusepol.2018. 04.043

Hoyos, I., Cañón-Barriga, J., Arenas-Suárez, T., Dominguez, F., and Rodríguez, B. A. (2018). Variability of regional atmospheric moisture over Northern South America: patterns and underlying phenomena. Clim. Dyn. 52, 893-911. doi: 10.1007/s00382-018-4172-9

Hoyos, I. C., Dominguez, F., Cañón-Barriga, J., Martínez, J. A., Nieto, R., Gimeno, L., et al. (2017). Moisture origin and transport processes in Colombia, northern South America. Clim. Dyn. 50, 971-990. doi: 10.1007/s00382-017-3653-6

Hugo, G. (2008). "Trends in land degradation in South America," in Management of Natural and Environmental Resources for Sustainable Agricultural Development, eds R. Stefanski, and P. Pasteris, (Portland, OR: World Meteorological Organization).

Ideam-Unal. (2018). Variabilidad Climática y Cambio Climático en Colombia. Bogotá, DC: Instituto de Hidrología, Meteorología y Estudios Ambientales Universidad Nacional de Colombia, 53.

IPCC (2013). "Climate Change 2013: the physical science basis," in Contribution of Working Group I to the Fifth Assessment Report of the Intergovernmental Panel on Climate Change, eds T.F. Stocker, D. Qin, G.-K. Plattner, M. Tignor, S.K. Allen, J. Boschung, et al. (Cambridge: Cambridge University Press), 1535.

IPCC (2014). "Summary for policymakers," Climate Change 2014: Impacts, Adaptation, and Vulnerability. Part A: Global and Sectoral Aspects. Contribution of Working Group II to the Fifth Assessment Report of the Intergovernmental Panel on Climate Change C.B. Field, V.R. Barros, D.J. Dokken, K.J. Mach, M.D. Mastrandrea, T.E. Bilir, et al. (Cambridge: Cambridge University Press), 1-32. 
IPCC (2019a). Climate Change and Land: An IPCC Special Report on Climate Change, Desertification, Land Degradation, Sustainable Land Management, Food Security, and Greenhouse Gas Fluxes in Terrestrial Ecosystems. Available online at: https://www.ipcc.ch/srccl/ (accessed September 28, 2019).

IPCC (2019b). IPCC Special Report on the Ocean and Cryosphere in a Changing Climate. Available online at: https://www.ipcc.ch/srocc/download/ (accessed September 28, 2019).

Jimenez-Muñoz, J. C., Barichivich, J., Mattar, C., Takahashi, K., SantamaríaArtigas, A., Sobrino, J. A., et al. (2018). Spatio-temporal patterns of thermal anomalies and drought over tropical forests driven by recent extreme climatic anomalies. Philos. Trans. R. Soc. B Biol. Sci. 373:20170300. doi: 10.1098/rstb. 2017.0300

Kellerhals, T., Brütsch, S., Sigl, M., Knüsel, S., Gäggeler, H. W., and Schwikowski, M. (2010). Ammonium concentration in ice cores: a new proxy for regional temperature reconstruction? J. Geophys. Res. 115:D16123. doi: 10.1029/ 2009JD012603

Lara, A., and Villalba, R. (1993). A 3,620-year temperature reconstruction from Fitzroya cupressoides tree rings in southern South America. Science 260, 11041106. doi: 10.1126/science.260.5111.1104

Lavado-Casimiro, W., Ronchail, J., Labat, D., Espinoza, J. C., and Guyot, J. L. (2012). A basin-scale analysis of rainfall and runoff in Peru (1969-2004): pacific, Titicaca and Amazonas drainages. Hydrol. Sci. J. 57, 41-18. doi: 10.1080/ 02626667.2012.672985

Lavado-Casimiro, W. S., Labat, D., Ronchail, J., Espinoza, J. C., and Guyot, J. L. (2013). Trends in rainfall and temperature in the Peruvian Amazon-Andes basin over the last 40 years (1965-2007). Hydrol. Proc. 41, 2944-2957.

Lavergne, A., Daux, V., Pierre, M., Stievenard, M., Srur, A. M., and Villalba, R. (2018). Past summer temperatures inferred from dendrochronological records of Fitzroya cupressoides on the eastern slope of the northern Patagonian Andes. J. Geophys. Res. Biogeosci. 123, 32-45. doi: 10.1002/2017JG003989

Lejeune, Q., Davin, E. L., Guillod, B. P., and Seneviratne, S. I. (2015). Influence of Amazonian deforestation on the future evolution of regional surface fluxes, circulation, surface temperature and precipitation. Clim. Dyn. 44, 2769-2786. doi: 10.1007/s00382-014-2203-8

López-Franca, N., Zaninelli, P. G., Carril, A. F., Menéndez, C. G., and Sánchez, E. (2016). Changes in temperature extremes for 21st century scenarios over South America derived from a multi-model ensemble of regional climate models. Clim. Res. 68, 151-167. doi: 10.3354/cr01393

Magrin, G. O., Marengo, J. A., Boulanger, J.-P., Buckeridge, M. S., Castellanos, E., Poveda, G., et al. (2014). "Central and South America," in Climate Change 2014: Impacts, Adaptation, and Vulnerability. Part B: Regional Aspects. Contribution of Working Group II to the Fifth Assessment Report of the Intergovernmental Panel on Climate Change, eds V. R. Barros, C. B. Field, D. J. Dokken, M. D. Mastrandrea, K. J. Mach, T. E. Bilir, et al. (Cambridge: Cambridge University Press), 1499-1566.

Makarieva, A. M., and Gorshkov, V. G. (2007). Biotic pump of the atmospheric moisture as driver of the hydrological cycle on land. Hydrol. Earth Syst Sci. 11, 1013-1033. doi: 10.5194/hess-11-1013-2007

Malhi, Y., Roberts, J. T., Betts, R. A., Killeen, T. J., Li, W., and Nobre, C. A. (2008). Climate change, deforestation, and the fate of the Amazon. Science 319, 169-172. doi: 10.1126/science.1146961

Marengo, J. A., Alves, L. M., Alvala, R. C. S., Cunha, A. P., Brito, S., Moraes, O. L. L., et al. (2018a). Climatic characteristics of the 2010-2016 drought in the semiarid Northeast Brazil region. Anais Acad. Brasil. Ciências 90(2 Suppl. 1), 1973-1985. doi: 10.1590/0001-3765201720170206

Marengo, J. A., Chou, S. C., Kay, G., Alves, L. M., Pesquero, J. F., Soares, W. R., et al. (2012a). Development of regional future climate change scenarios in South America using the Eta CPTEC/HadCM3 climate change 87 projections: climatology and regional analyses for the Amazon, São Francisco and the Paraná River Basins. Clim. Dyn. 38, 9-12, 1829-1848.

Marengo, J. A., Souza, C. M., Thonicke, K., Burton, C., Halladay, K., Betts, R. A., et al. (2018b). Changes in climate and land use over the amazon region: current and future variability and trends. Front. Earth Sci. 6:228. doi: 10.3389/feart. 2018.00228

Marengo, J. A., Tomasella, J., Soares, W. R., Alves, L. M., and Nobre, C. A. (2012b). Extreme climatic events in the Amazon basin. Theor. Appl. Climatol. 107, 73-85. doi: 10.1007/s00704-011-0465-1
Marengo, J. A., and Espinoza, J. C. (2016). Extreme seasonal droughts and floods in Amazonia: causes, trends and impacts. Int. J. Climatol. 36, 1033-1050. doi: $10.1002 /$ joc. 4420

Marengo, J. A., Jones, R., Alves, L. M., and Valverde, M. C. (2009). Future change of temperature and precipitation extremes in South America as derived from the PRECIS regional climate modeling system. Int. J. Climatol. 29, 2241-2255. doi: $10.1002 /$ joc. 1863

Marengo, J. A., Tomasella, J., Alves, L. M., Soares, W. R., and Rodriguez, D. A. (2011). The drought of 2010 in the context of historical droughts in the Amazon region. Geophys. Res. Lett. 38, L12703. doi: 10.1029/2011gl047436

Marengo, J. A., Tomasella, J., and Uvo, C. (1998). Long-term streamflow and rainfall fluctuations in tropical South America: Amazonia, Eastern Brazil and Northwest Peru. J. Geophys. Res. 103, 1775-1178.

Martínez, R., Ruiz, D., Andrade, M., Blacutt, L., Pabón, D., Jaimes, E., et al. (2011). "Synthesis of the climate of the tropical andes," in Climate Change and Biodiversity in the Tropical Andes, eds S. Herzog, R. Martinez, P.M. Jorgensen, H. Tiessen, (São José dos Campos - Paris: Inter American Institute for Global Change Research (IAI) - Scientific Committee on Problems of the Environment (SCOPE)), 97-109.

Masiokas, M. H., Cara, L., Villalba, R., Pitte, P., Luckman, B. H., Toum, E., et al. (2019). Streamflow variations across the Andes $\left(18^{\circ}-55^{\circ} \mathrm{S}\right)$ during the instrumental era. Sci. Rep. 9:17879. doi: 10.1038/s41598-019-53981-x

Masiokas, M. H., Rivera, A., Espizua, L. E., Villalba, R., Delgado, S., and Aravena, J. C. (2009). Glacier fluctuations in extratropical South America during the past 1000years. Palaeogeogr. Palaeoclimatol. Palaeoecol. 281, 242-268. doi: 10.1016/ j.palaeo.2009.08.006

Masiokas, M. H., Villalba, R., Luckman, B. H., Le Quesne, C., and Aravena, J. C. (2006). Snowpack variations in the central andes of argentina and chile, (1951)2005. Large-scale atmospheric influences and implications for water resources in the region. J. Clim. 19, 6334-6352. doi: 10.1175/jcli3969.1

Masiokas, M. H., Villalba, R., Luckman, B. H., and Mauget, S. (2010). Intra- to multidecadal variations of snowpack and streamflow records in the andes of chile and argentina between $30^{\circ}$ and $37^{\circ}$ S. J. Hydrometeorol. 11, 822-831. doi: 10.1175/2010jhm1191.1

Meehl, G. A., Covey, C., Delworth, T., Latif, M., McAvaney, B., Mitchell, J. F. B., et al. (2007). The WCRP CMIP3 multimodel dataset: a new era in climate change research. Bull. Am. Meteorol. Soc. 88, 1383-1394. doi: 10.1175/bams88-9-1383

Menéndez, C. G., Zaninelli, P. G., Carril, A. F., and Sánchez, E. (2016). Hydrological cycle, temperature, and land surface-atmosphere interaction in the La Plata Basin during summer: response to climate change. Clim. Res. 68, 231-241. doi: 10.3354/cr01373

Mernild, S. H., Liston, G. E., Hiemstra, C. A., Yde, J. C., and Casassa, G. (2018). Annual river runoff variations and trends for the andes cordillera. J. Hydrometeorol. 19, 1167-1189. doi: 10.1175/jhm-d-17-0094.1

Metternicht, G., and Zinck, J. A. (2016). "Geomorphic landscape approach to mapping soil degradation and hazard prediction in semi-arid environments: salinization in the cochabamba valleys, bolivia," in Geopedology, eds J. A. Zinck, G. Metternicht, G. Bocco, and H. F. Del Valle, (Cham: Springer).

Minvielle, M., and Garreaud, R. D. (2011). Projecting rainfall changes over the south american altiplano. J. Clim. 24, 4577-4583. doi: 10.1175/jcli-d-1100051.1

Moberg, A., Sonechkin, D. M., Holmgren, K., Datsenko, N. M., and Karlen, W. (2005). Highly variable Northern Hemisphere temperatures reconstructed from low- and high-resolution proxy data. Nature 433, 613-617. doi: 10.1038/ nature 03265

Molina, R. D., Salazar, J. F., Martínez, J. A., Villegas, J. C., and Arias, P. A. (2019). Forest-induced exponential growth of precipitation along climatological wind streamlines over the Amazon. J. Geophys. Res. Atmos. 124, 2589-2599. doi: 10.1029/2018jd029534

Molina-Carpio, J., Espinoza, J. C., Vauchel, P., Ronchail, J., Gutierrez Caloir, B., Guyot, J.-L., et al. (2017). Hydroclimatology of the Upper Madeira River basin: spatio-temporal variability and trends. Hydrol. Sci. J. 62, 911-927. doi: 10.1080/ 02626667.2016.1267861

Montecinos, A., and Aceituno, P. (2003). Seasonality of the ENSO-related rainfall variability in central chile and associated circulation anomalies. J. Clim. 16, 281-296. doi: 10.1175/1520-0442(2003)016<0281:soterr >2.0.co;2 
Mora, D. E., Campozano, L., Cisneros, F., Wyseure, G., and Willems, P. (2014). Climate changes of hydrometeorological and hydrological extremes in the Paute basin, Ecuadorean Andes. Hydrol. Earth Syst. Sci. 18, 631-648. doi: 10.5194/ hess-18-631-2014

Morales, M. S., Christie, D. A., Villalba, R., Argollo, J., Pacajes, J., Silva, J. S., et al. (2012). Precipitation changes in the South American Altiplano since 1300AD reconstructed by tree-rings. Clim. Past 8, 653-666. doi: 10.5194/cp-8-6532012

Morán-Tejeda, E., Bazo, J., López-Moreno, J. I., Aguilar, E., Azorín-Molina, C., Martínez, R., et al. (2016). Climate trends and variability in Ecuador (19662011). Int. J. Climatol. 36, 3839-3855. doi: 10.1002/joc.4597

Morera, S. B., Condom, T., Crave, A., Steer, P., and Guyot, J. L. (2017). The impact of extreme El Niño events on modern sediment transport along the western Peruvian Andes (1968-2012). Sci. Rep. 7:11947. doi: 10.1038/s41598017-12220-x

Mourre, L., Condom, T., Junquas, C., Lebel, T. E., Sicart, J., Figueroa, R., et al. (2016). Spatio-temporal assessment of WRF, TRMM and in situ precipitation data in a tropical mountain environment (Cordillera Blanca, Peru). Hydrol. Earth Syst. Sci. 20, 125-141. doi: 10.5194/hess-20-125-2016

Neukom, R., Gergis, J., Karoly, D. J., Wanner, H., Curran, M., Elbert, J., et al. (2014). Inter-hemispheric temperature variability over the past millennium. Nat. Clim. Change 4, 362-367. doi: 10.1038/nclimate2174

Neukom, R., Rohrer, M., Calanca, P., Salzmann, N., Huggel, C., Acuña, D., et al. (2015). Facing unprecedented drying of the Central Andes? Precipitation variability over the period AD 1000-2100. Environ. Res. Lett. 10:084017. doi: 10.1088/1748-9326/10/8/084017

Nobre, C. A., Sampaio, G., Borma, L. S., Castilla-Rubio, J. C., Silva, J. S., and Cardoso, M. (2016). Land-use and climate change risks in the Amazon and the need of a novel sustainable development paradigm. Proc. Natl. Acad. Sci. U.S.A. 113, 10759-10768. doi: 10.1073/pnas.1605516113

Novello, V. F., Cruz, F. W., Karmann, I., Burns, S. J., Stríkis, N. M., Vuille, M., et al. (2012). Multidecadal climate variability in Brazil's Nordeste during the last 3000 years based on speleothem isotope records. Geophys. Res. Lett. 39:L23706. doi: 10.1029/ 2012GL053936

Novello, V. F., Vuille, M., Cruz, F. W., Stríkis, N. M., de Paula, M. S., Edwards, R. L., et al. (2016). Centennial-scale solar forcing of the South American monsoon system recorded in stalagmites. Sci. Rep. 6:24762. doi: 10.1038/srep24762

Ohmura, A. (2012). Enhanced temperature variability in high-altitude climate change. Theor. Appl. Climatol. 110, 499-508. doi: 10.1007/s00704-012-0687-x

Olsson, T., Kämäräinen, M., Santos, D., Seitola, T., Tuomenvirta, H., Haavisto, R., et al. (2017). Downscaling climate projections for the Peruvian coastal ChancayHuaral Basin to support river discharge modeling with WEAP. J. Hydrol. Reg. Stud. 13, 26-42. doi: 10.1016/j.ejrh.2017.05.011

Ovando, A., Tomasella, J., Rodriguez, D. A., Martinez, J. M., Siqueira-Junior, J. L., Pinto, G. L. N., et al. (2016). Extreme flood events in the Bolivian Amazon wetlands. J. Hydrol. Reg. Stud. 5, 293-308. doi: 10.1016/j.ejrh.2015.11.004

Oyama, M. D., and Nobre, C. A. (2003). A new climate-vegetation equilibrium state for tropical South America. Geophys. Res. Lett. 30:2199. doi: 10.1029/ $2003 \mathrm{gl} 018600$

Pabón, J. D. (2012). Cambio climático en Colombia: tendencias en la segunda mitad del siglo XX y escenarios posibles para el siglo XXI. Rev. Acad. Colomb. Cienc. 36, 127-144.

Paiva, R. C. D., Buarque, D. C., Collischonn, W., Bonnet, M.-P., Frappart, F., Calmant, S., et al. (2013). Large-scale hydrologic and hydrodynamic modeling of the Amazon River basin. Water Resour. Res. 49, 1226-1243. doi: 10.1002/ wrcr.20067

Paiva, R. C. D., Collischonn, W., and Tucci, C. E. M. (2011). Large scale hydrologic and hydrodynamic modeling using limited data and a GIS based approach. J. Hydrol. 406, 170-181. doi: 10.1016/j.jhydrol.2011.06.007

Palazzi, E., Filippi, L., and von Hardenberg. (2017). Insights into elevationdependent warming in the Tibetan Plateau-Himalayas from CMIP5 model simulations. J. Clim. Dyn. 48:3991. doi: 10.1007/s00382-016-3316-Z

Palazzi, E., Mortarini, L., Terzago, S., and von Hardenberg, J. (2019). Elevationdependent warming in global climate model simulations at high spatial resolution. Clim. Dyn. 52, 2685-2702. doi: 10.1007/s00382-018-4287-z

Palomino-Lemus, R., Córdoba-Machado, S., Gámiz-Fortis, S. R., Castro-Díez, Y., and Esteban-Parra, M. J. (2015). Summer precipitation projections over northwestern South America from CMIP5 models. Glob. Planet. Change 131, 11-23. doi: 10.1016/j.gloplacha.2015.05.004

Palomino-Lemus, R., Córdoba-Machado, S., Gámiz-Fortis, S. R., Castro-Díez, Y., and Esteban-Parra, M. J. (2017). Climate change projections of boreal summer precipitation over tropical America by using statistical downscaling from CMIP5 models. Environ. Res. Lett. 12:124011. doi: 10.1088/1748-9326/aa9bf7

Palomino-Lemus, R., Córdoba-Machado, S., Gámiz-Fortis, S. R., Castro-Díez, Y., and Esteban-Parra, M. J. (2018). High-resolution boreal winter precipitation projections over tropical America from CMIP5 models. Clim. Dyn. 51, 17731792. doi: 10.1007/s00382-017-3982-5

Peduzzi, P., Herold, C., and Silverio, W. (2010). Assessing high altitude glacier thickness, volume and area changes using field, GIS and remote sensing techniques: the case of Nevado Coropuna (Peru). Cryosphere 4, 313-323. doi: 10.5194/tc-4-313-2010

Pepin, N., Bradley, R. S., Diaz, H. F., Baraer, M., Caceres, E. B., Forsythe, N., et al. (2015). Elevation-dependent warming in mountain regions of the world. Nat. Clim. Change 5:424. doi: 10.1038/nclimate2563

Posada-Marín, J. A., Rendon, A. M., Salazar, J. F., Mejía, J. F., and Villegas, J. C. (2019). WRF downscaling improves ERA-Interim representation of precipitation around a tropical Andean valley during El Niño: implications for GCM-scale simulation of precipitation over complex terrain. Clim. Dyn. 52, 3609-3629. doi: 10.1007/s00382-018-4403-0

Poveda, G., Jaramillo, L., and Vallejo, L. F. (2014). Seasonal precipitation patterns along pathways of South American low-level jets and aerial rivers. Water Resour. Res. 50, 98-118. doi: 10.1002/2013WR014087

Preston, D. (2016). "Interpreting environmental changes in the southern bolivian andes: rural responses and political actions," in The End of Desertification? Disputing Environmental Change in the Drylands, eds R. H. Behnke, and M. Mortimore, (Berlin: Springer).

Quintana, J. M., and Aceituno, P. (2012). Changes in the rainfall regime along the extratropical west coast of South America (Chile): 30-43 S. Atmósfera 25, 1-22.

Quintana-Gómez, R. A. (1999). Trends of Maximum and minimum Temperatures in Northern South America. J. Clim. 12, 2104-2112. doi: 10.1175/15200442(1999)012<2104:tomamt>2.0.co;2

Rabatel, A., Francou, B., Soruco, A., Gomez, J., Caìceres, B., Ceballos, J. L., et al. (2013). Current state of glaciers in the tropical Andes: a multi-century perspective on glacier evolution and climate change. Cryosphere 7, 81-102. doi: 10.5194/tc-7-81-2013

Ragettli, S., Immerzeel, W. W., and Pellicciotti, F. (2016). Contrasting climate change impact on river flows from high-altitude catchments in the Himalayan and Andes Mountains. Proc. Natl. Acad. Sci. U.S.A. 113, 9222-9227. doi: 10. 1073/pnas.1606526113

Rangwala, I., and Miller, J. R. (2012). Climate change in mountains: a review of elevation-dependent warming and its possible causes. Clim. Change 114, 527-547. doi: 10.1007/s10584-012-0419-3

Rasmussen, K. L., Zuluaga, M. D., and Houze, R. A. Jr. (2014). Severe convection and lightning in subtropical South America. Geophys. Res. Lett. 41, 7359-7366. doi: $10.1002 / 2014 \mathrm{gl} 061767$

Rau, P., Bourrel, L., Labat, D., Melo, P., Dewitte, B., Frappart, F., et al. (2016). Regionalization of rainfall over the Peruvian Pacific slope and coast. Int. J. Climatol. 37, 143-158. doi: 10.1002/joc.4693

Restrepo, J. D., Kettner, A. J., and Syvitski, J. P. M. (2015). Recent deforestation causes rapid increase in river sediment load in the Colombian Andes. Anthropocene 10, 13-28. doi: 10.1016/j.ancene.2015.09.001

Rodriguez-Eraso, N., Armenteras-Pascual, D., and Retana-Alumbreros, J. (2013). Land use and land cover change in the Colombian Andes: dynamics and future scenarios. J. Land Use Sci. 8, 154-174. doi: 10.1080/1747423X.2011.650228

Ronchail, J., Espinoza, J. C., Drapeau, G., Sabot, M., Cochonneau, G., and Schor, T. (2018). The flood recession period in Western Amazonia and its variability during the 1985-2015 period. J. Hydrol. Reg. Stud. 15, 16-30. doi: 10.1016/j.ejrh. 2017.11.008

Russell, A. M., Gnanadesikan, A., and Zaitchik, B. (2017). Are the central andes mountains a warming hot spot? J. Clim. 30, 3589-3608. doi: 10.1175/jcli-d-160268.1

Rusticucci, M., Zazulie, N., and Raga, G. B. (2014). Regional winter climate of the southern central Andes: assessing the performance of ERA-Interim for climate studies. J. Geophys. Res. Atmos. 119, 8568-8582. doi: 10.1002/2013JD021167 
Saavedra, F., Kampf, S., Fassnacht, S. R., and Sibold, J. S. (2018). Changes in Andes snow cover from MODIS data, 2000-2016. Cryosphere 12, 1027-1046. doi: 10.5194/tc-12-1027-2018

Sakamoto, M. S., Ambrizzi, T., and Poveda, G. (2011). Moisture sources and life cycle of convective systems over western colombia. Adv. Meteorol. 2011, 1-11. doi: $10.1155 / 2011 / 890759$

Salazar, A., Baldi, G., Hirota, M., Syktus, J., and McAlpine, C. (2015). Land use and land cover change impacts on the regional climate of non-Amazonian South America: a review. Glob. Planet. Change 128, 103-119. doi: 10.1016/j.gloplacha. 2015.02.009

Salazar, A., Sánchez-Andrade, A., Villegas, J. C., Salazar-Villegas, J. F., RuizCarrascal, D., Sitch, S., et al. (2018). The ecology of peace: preparing Colombia for new political and planetary climates. Front. Ecol. Environ. 16:1950. doi: $10.1002 /$ fee. 1950

Salazar, J. F., Villegas, J. C., Rendón, A. M., Rodríguez, E., Hoyos, I., MercadoBettín, D., et al. (2018). Scaling properties reveal regulation of river flows in the Amazon through a forest reservoir Hydrology and Earth System Sciences. 22, 1735-1748. doi: 10.5194/hess-22-1735-2018

Salazar, L. F., Nobre, C. A., and Oyama, M. D. (2007). Climate change consequences on the biome distribution in tropical South America. Geophys. Res. Lett. 34:L09708. doi: 10.1029/2007GL029695

Sánchez, E., Solman, S., Remedio, A. R. C., Berbery, H., Samuelsson, P., Da Rocha, R. P., et al. (2015). Regional climate modelling in CLARIS-LPB: a concerted approach towards twenty first century projections of regional temperature and precipitation over South America. Clim. Dyn. 45, 2193-2212. doi: 10.1007/ s00382-014-2466-0

Santini, W., Martinez, J.-M., Espinoza-Villar, R., Cochonneau, G., Vauchel, P., Moquet, J.-S., et al. (2015). Sediment budget in the Ucayali River basin, an Andean tributary of the Amazon River. Proc. IAHS 367, 320-325. doi: 10.5194/ piahs-367-320-2015

Satgé, F., Espinoza, R., Zolá, R., Roig, H., Timouk, F., Molina, J., et al. (2017). Role of climate variability and human activity on poopó lake droughts between 1990 and 2015 assessed using remote sensing data. Remote Sens. 9:218. doi: $10.3390 /$ rs 9030218

Sayago, J. M., and Collantes, M. M. (2016). “Geopedology and land degradation in north-west argentina," in Geopedology, eds J. A. Zinck, G. Metternicht, G. Bocco, and H. F. Del Valle, (Berlin: Springer).

Schauwecker, S., Rohrer, M., Acuña, D., Cochachin, A., Dávila, L. R., Frey, H., et al. (2014). Climate trends and glacier retreat in the Cordillera Blanca, Peru, revisited. Glob. Planet. Change 119, 85-97. doi: 10.1016/j.gloplacha.2014.05.005

Schoolmeester, T., Saravia, M., Andresen, M., Postigo, J., Valverde, A., Jurek, M., et al. (2016). Outlook on Climate Change Adaptation in the Tropical Andes mountains. Mountain Adaptation Outlook Series. Nairobi, Arendal, Vienna and Lima: United Nations Environment Programme, GRIDArendal and CONDESAN.

Seiler, C., Hutjes, R. W. A., and Kabat, P. (2013a). Climate variability and trends in Bolivia. J. Appl. Meteorol. Climatol. 52, 130-146. doi: 10.1175/jamc-d-12s0105.1

Seiler, C., Hutjes, R. W., and Kabat, P. (2013b). Likely ranges of climate change in bolivia. J. Appl. Meteor. Climatol. 52, 1303-1317. doi: 10.1175/jamc-d-120224.1

Sierra, J. P., Arias, P. A., and Vieira, S. C. (2015). Precipitation over northern south america and its seasonal variability as simulated by the CMIP5 models. Adv. Meteorol. 2015, 21-22.

Sierra, J. P., Arias, P. A., Vieira, S. C., and Agudelo, J. (2017). How well do CMIP5 models simulate the low-level jet in western Colombia? Clim. Dyn. 51, 2247-2265. doi: 10.1007/s00382-017-4010-5

Silva, Y., Takahashi, K., and Chávez, R. (2008). Dry and wet rainy seasons in the Mantaro river basin (Central Peruvian Andes). Adv. Geosci. 14, 261-264. doi: 10.5194/adgeo-14-261-2008

Solman, S. A. (2013). Regional climate modeling over south america: a review. Adv. Meteorol. 2013:504357.

Solman, S. A., and Blazquez, J. (2019). Multiscale precipitation variability over South America: analysis of the added value of CORDEX RCM simulations. Clim. Dyn. 53, 1547-1565. doi: 10.1007/s00382-019-04689-1

Sombroek, W. (2001). Spatial and Temporal Patterns of Amazon Rainfall. AMBIO J. Hum. Environ. 30, 388-396. doi: 10.1579/0044-7447-30. 7.388
Souvignet, M., Oyarzún, R., Verbist, K. M. J., Gaese, H., and Heinrich, J. (2012). Hydrometeorological trends in semi-arid north-central Chile $\left(29-32^{\circ} \mathrm{S}\right)$ : water resourcesimplicationsfor a fragileAndean region. Hydrol. Sci. J. 57, 479-495. doi: 10.1080/02626667.2012.665607

Taylor, K. E., Stouffer, R. J., and Meehl, G. A. (2012). An overview of CMIP5 and the experiment design. Bull. Am. Meteorol. Soc. 93, 485-498. doi: 10.1175/bams-d11-00094.1

Thibeault, J., Seth, A., and Wang, G. (2012). Mechanisms of summertime precipitation variability in the Bolivian Altiplano: present and future. Int. J. Climatol. 32, 2033-2041. doi: 10.1002/joc.2424

Urrutia, R., and Vuille, M. (2009). Climate change projections for the tropical Andes using a regionalclimate model: temperature and precipitation simulations for the end of the 21st century. J. Geophys. Res. Atmos. Atmos. 114:D02108. doi: 10.1029/2008JD011021

Urrutia-Jalabert, R., González, M. E., González-Reyes, Á, Lara, A., and Garreaud, R. (2018). Climate variability and forest fires in central and south-central Chile. Ecosphere 9:e02171. doi: 10.1002/ecs2.2171

Vauchel, P., Santini, W., Guyot, J. L., Moquet, J. S., Martinez, J. M., Espinoza, J. C., et al. (2017). A reassessment of the suspended sediment load in the Madeira River basin from the Andes of Peru and Bolivia to the Amazon River in Brazil, based on 10 years of data from the HYBAM monitoring programme. J. Hydrol. 553, 35-48. doi: 10.1016/j.jhydrol.2017.07.018

Vega-Jácome, F., Lavado-Casimiro, W. S., and Felipe-Obando, O. G. (2017). Assessing hydrological changes in a regulated river system over the last 90 years in Rimac Basin (Peru). Theor. Appl. Climatol. 132, 347-362. doi: 10.1007/ s00704-017-2084-y

Viale, M., and Nuñez, M. N. (2011). Climatology of winter orographic precipitation over the subtropical central andes and associated synoptic and regional characteristics. J. Hydrometeorol. 12, 481-507. doi: 10.1175/2010JHM 1284.1

Vicente-Serrano, S. M., López-Moreno, J. I., Correa, K., Avalos, G., Bazo, J., AzorinMolina, C., et al. (2018). Recent changes in monthly surface air temperature over Peru, 1964-2014. Int. J. Climatol. 38, 283-306. doi: 10.1002/joc.5176

Villalba, R. (1990). Climatic Fluctuations in Northern Patagonia during the Last 1000 Years as Inferred from Tree-Ring Records. Quat. Res. 34, 346-360. doi: 10.1016/0033-5894(90)90046-n

Villalba, R. (1994). Tree-ring and glacial evidence for the medieval warm epoch and the little ice age in southern South America. Clim. Change 26, 183-197. doi: 10.1007/978-94-011-1186-7_4

Villalba, R., Cook, E. R., Jacoby, G. C., D’Arrigo, R. D., Veblen, T. T., and Jones, P. D. (1998). Tree-ring based reconstructions of northern Patagonia precipitation since A.D. 1600. Holocene 8, 659-674. doi: 10.1191/ 095968398669095576

Villalba, R., Grosjean, M., and Kiefer, T. (2009). Long-term multi-proxy climate reconstructions and dynamics in South America (LOTRED-SA): state of the art and perspectives. Palaeogeogr. Palaeoclimatol. Palaeoecol. 281, 175-179. doi: 10.1016/j.palaeo.2009.08.007

Villalba, R., Lara, A., Boninsegna, J. A., Masiokas, M., Delgado, S., Aravena, J. C., et al. (2003). Large-scale temperature changes across the southern Andes: 20thcentury variations in the context of the past 400 years. Clim. Change 59, 177-232. doi: 10.1007/978-94-015-1252-7_10

Villalba, R., Lara, A., Masiokas, M. H., Urrutia, R., Luckman, B. H., Marshall, G. J., et al. (2012). Unusual southern hemisphere tree growth patterns induced by changes in the southern annular mode. Nat. Geosci. 5, 793-798. doi: 10.1038/ ngeo1613

Vuille, M., and Bradley, R. S. (2000). Mean annual temperature trends and their vertical structure in the tropical Andes. Geophys. Res. Lett. 27, 3885-3888. doi: 10.1029/2000gl011871

Vuille, M., Burns, S. J., Taylor, B. L., Cruz, F. W., Bird, B. W., Abbott, M. B., et al. (2012). A review of the south american monsoon history as recorded in stable isotopic proxies over the past two millennia. Clim. Past 8, 1309-1321. doi: 10.5194/cp-8-1309-2012

Vuille, M., Francou, B., Wagnon, P., Juen, I., Kaser, G., Mark, B. G., et al. (2008). Climate change and tropical Andean glaciers: past, present and future. Earth-Sci. Rev. 89, 79-96. doi: 10.1016/j.earscirev.2008.04.002

Vuille, M., Franquist, E., Garreaud, R., Lavado Casimiro, W. S., and Cáceres, B. (2015). Impact of the global warming hiatus on Andean temperature. J. Geophys. Res. Atmos. 120, 3745-3757. doi: 10.1002/2015jd023126 
Wang, S., Huang, J., He, Y., and Guan, Y. (2014). Combined effects of the pacific decadal oscillation and el niño-southern oscillation on global land dry-wet changes. Nat. Sci. Rep. 4, 1-8. doi: 10.1038/srep06651

Wang, X.-Y., Li, X., Zhu, J., and Tanajura, C. A. S. (2018). The strengthening of Amazonian precipitation during the wet season driven by tropical sea surface temperature forcing. Environ. Res. Lett. 13:094015. doi: 10.1088/1748-9326/ aadbb9

Wongchuig-Correa, S., Dias, de Paiva, R. C., Espinoza, J. C., and Collischonn, W. (2017). Multi-decadal hydrological retrospective: case study of amazon floods and droughts. 54, 667-684. doi: 10.1016/j.jhydrol.2017. 04.019

Young, B., Young, K. R., and Josse, C. (2011). "Vulnerability of tropical Andean ecosystems to climate change," in Climate Change and Biodiversity in the Tropical Andes, eds S. K. Herzog, R. Martinez, P. M. Jorgensen, and H. Tiessen, (São José dos Campos - Paris: Inter American Institute for Global Change Research (IAI) - Scientific Committee on Problems of the Environment (SCOPE)), 170-181.

Young, K. N. (2009). Andean land use and biodiversity: humanized landscapes in a time of changes. Ann. Missouri Bot. Garden 96, 492-507. doi: 10.3417/200 8035

Zaninelli, P. G., Menéndez, C. G., Falco, M., et al. (2019). Future hydroclimatological changes in South America based on an ensemble of regional climate models. Clim. Dyn. 52, 819-830. doi: 10.1007/s00382-018-4225-0

Zazulie, N., Rusticucci, M., and Raga, G. B. (2017). Regional climate of the subtropical central Andes using high-resolution CMIP5 models-part I: past performance (1980-2005). Clim. Dyn. 49, 3937-3957. doi: 10.1007/s00382-0173560- $\mathrm{x}$

Zazulie, N., Rusticucci, M., and Raga, G. B. (2018). Regional climate of the Subtropical Central Andes using high-resolution CMIP5 models. Part II: future projections for the twenty-first century. Clim. Dyn. 51:2913. doi: 10.1007/ s00382-017-4056-4

Zubieta, R., Getirana, A., Espinoza, J. C., Lavado-Casimiro, W., and Aragon, L. (2017). Hydrological modeling of the Peruvian-Ecuadorian Amazon basin using GPM-IMERG satellite-based precipitation dataset. Hydrol. Earth Syst. Sci. 21, 3543-3555. doi: 10.5194/hess-21-3543-2017

Zulkafli, Z., Buytaert, W., Manz, B., Rosas, C. V., Willems, P., Lavado-Casimiro, W., et al. (2016). Projected increases in the annual flood pulse of the Western Amazon. Environ. Res. Lett. 11:014013. doi: 10.1088/1748-9326/11/1/ 014013

Zulkafli, Z., Buytaert, W., Onof, C., Manz, B., Tarnavsky, E., Lavado, W., et al. (2014). A comparative performance analysis of TRMM 3B42 (TMPA) versions 6 and 7 for hydrological applications over Andean-Amazon River basins. J. Hydrometeorol. 15, 581-592. doi: 10.1175/jhm-d-13-094.1

Zuluaga, M. D., and Houze, R. A. (2015). Extreme convection of the near-equatorial americas, africa, and adjoining oceans as seen by TRMM. Monthly Weather Rev. 143, 298-316. doi: 10.1175/mwr-d-14-00109.1

Conflict of Interest: The authors declare that the research was conducted in the absence of any commercial or financial relationships that could be construed as a potential conflict of interest.

Copyright (C) 2020 Pabón-Caicedo, Arias, Carril, Espinoza, Borrel, Goubanova, Lavado-Casimiro, Masiokas, Solman and Villalba. This is an open-access article distributed under the terms of the Creative Commons Attribution License (CC BY). The use, distribution or reproduction in other forums is permitted, provided the original author(s) and the copyright owner(s) are credited and that the original publication in this journal is cited, in accordance with accepted academic practice. No use, distribution or reproduction is permitted which does not comply with these terms. 